\title{
EFFECT OF SPRAYING WITH SOME ANTIOXIDANTS ON GROWTH, YIELD, FRUIT QUALITY AND NUTRITIONAL STATUS OF 'NAVEL ORANGE' TREES
}

\author{
[128] \\ Eman M. Abdelmoniem *, El-Shazly S.A., El-Gazzar A.A. and Noha A. Mansour \\ Horticulture Dept., Fac. of Agric., Ain Shams Univ., P.O. Box 68, Hadayek Shoubra 11241, \\ Cairo, Egypt \\ ${ }^{*}$ Corresponding author: Eman_Abdelmoniem@agr.asu.edu.eg \\ Received 26 May, 2019 \\ Accepted 25 June, 2019
}

\begin{abstract}
This study was carried out through two consecutive seasons 2016 and 2017 to investigate the effect of spraying with some antioxidants on vegetative growth, yield, fruit quality and nutritional status of twelve years old 'Navel orange' trees grafted on sour orange rootstock and grown in a private orange orchard in Qalubia Governorate, Egypt cultivated in a silty clay loam soil. This experiment involved three antioxidant materials named (salicylic acid, citric acid and folic acid) and each one spraying by three levels of each of with $(250,500$ and $1000 \mathrm{ppm}$ ) from each salicylic, citric and folic acid plus control treatment so the experiment included ten treatments. Selected trees were sprayed three times in March, in May in July by aqueous solution of salicylic acid, citric acid and folic acid until the point of runoff. The highest values of vegetative growth were obtained by spraying by 500 ppm salicylic acid, 1000 ppm citric acid and $500 \mathrm{ppm}$ folic acid. Regarding to yield, results pointed out that the foliar spraying with 500 ppm salicylic acid, 500 ppm citric acid and $250 \mathrm{ppm}$ folic acid gave the highest values of yield. Treatments of $500 \mathrm{ppm}$ salicylic acid, $250 \mathrm{ppm}$ citric acid and 250 ppm folic acid gave the highest values of physical and chemical fruit properties. In respect to nutrients content, the highest values of macronutrients were obtained by spraying of 250 ppm folic acid, while that spraying by 1000 ppm salicylic acid and $250 \mathrm{ppm}$ folic acid gave the highest values of micronutrients. Therefore, using treatment 500 ppm salicylic acid may be recommended from economical point of view and as good treatment for enhancing Navel orange growth, yield, fruit quality and nutritional status especially under old citrus orchards.
\end{abstract}

Keywords: Navel Orange; Antioxidants; Citric acid; Folic acid; Salicylic acid; Growth and productivity

\section{INTRODUCTION}

Citrus occupies a large economic importance among fruit crops in Egypt. The total area of citrus reached about 477.510 feddan with fruitful area about 444.271 feddan and the production is close to 4.451 .644 tons. Citrus exports is about $1.5 \mathrm{mil}-$ lion tons (U.P.E.H.C., 2016). The total area of oranges with various varieties occupy about 326.484 feddan with fruitful area about 306,856 feddan and the production is close to 3.147 .545 tons with a productivity 10.257 tons / feddan (M.A.L.R., 2017).

Navel orange (Citrus sinensis L. Osbeck) is one of the most popular citrus fruit in Egypt; for its delicious, taste and nutrition, besides being rich in vitamin C and several minerals (Aly et al 2015).

Navel orange trees occupies its first position for other orange varieties. According to economic affairs sector in 2017 total areas of Navel orange trees reached about 155,037 fedden and fruitful area about 153.077 fedden which production an average of 1.6 million tons with productivity about 10.6 tons/fedden. Qalyubiya occupies second governorate after Beheira in terms of total area and production.

Recently, antioxidants are put forward for improving yield, safety and producing organic fruits in different fruit trees. There are two types of antioxidants, the first type of antioxidants is the enzymatic antioxidants like superoxide dismutase, catalase, glutathione-s-transferase, glutathione peroxidase, ascorbate oxidase and polyphenol oxidase, and the second type of antioxidants is non-enzymatic antioxidants such as total reduced glutathione, 
vitamins ( $A, C, E$, and $M$ (folic acid)), organic acids (ascorbic acid, citric acid and salicylic acid) (Vinoth et al 2017).

These compounds as antioxidants have useful effects on catching free radicals such as the active oxygen species namely superoxide anion, singlet oxygen, hydroxyl radicals, hydrogen peroxide and ozone that biosynthesized during plant metabolism. Leaving free radicals without chelating or catching causing loss of plasma membrane permeability, oxidation of lipids and death of cells (El Sayed et al 2000).

Antioxidants have an important role in enhancing the biosynthesis of natural hormones, photosynthesis, nutrient uptake, plant protection from biotic and abiotic stresses and biosynthesis of plant pigments and sugars, as they increase antioxidant defense systems and reduce the reactive oxygen species, then suggested recently that it is mainly involved in the growth of flowering plants and the development of fruit (Rao et al 2000).

Navel orange trees are exposed in Egypt to environmental stress under environmental conditions, which is characterized by high temperature and low humidity during the various stages of growth from the beginning of the growth of trees in Spring to harvest the fruits in November, causing flower and fruit drop, and therefore decline yield and fruit quality.

With the foregoing background, the scope of the present research was to evaluate the effect of spraying with some antioxidant materials named (salicylic acid, citric acid and folic acid) on improving vegetative growth, yield, fruit quality and nutritional status of Navel orange trees budded on sour orange rootstock.

\section{MATERIALS AND METHODS}

Field experiment was carried out in a private orange orchard in Qalubia Governorate, Egypt through 2016 and 2017 seasons. Twelve years old Navel orange trees (Citrus sinensis L.) budded on sour orange trees
(Citrus aurantium L.) rootstock were used planted at $2.5 \times 5$ meter a plant and surface irrigation system was used. The soil texture class was silty clay loam (Table 1). Soil samples were taken from two locations of the experimental area at $0-30$ and $30-60 \mathrm{~cm}$ from the soil surface for physical and chemical analysis. Soil samples were analyzed for texture, $\mathrm{pH}$ and electric conductivity (EC) using water extract (1: 2.5) method, total calcium carbonate $(\mathrm{CaCO} 3 \%)$ determined with calcimeter method and organic matter (O.M. \%) was determined with using potassium dichromate (Chapman and Pratt, 1961). Phosphorus was extracted using sodium bicarbonate (Olsen et al 1954). Potassium (K), calcium $(\mathrm{Ca})$, magnesium $(\mathrm{Mg})$ and sodium $(\mathrm{Na})$ were extracted using ammonium acetate (Jackson, 1958). Iron (Fe), manganese (Mn), zinc $(\mathrm{Zn})$ and copper $(\mathrm{Cu})$ were extracted using DTPA, (Lindsay and Norvell, 1978). Physical and Chemical properties of the study soil are presented in Tables (1 and 2). The experiment was applied on "40 tree", all trees were selected on the basis of resemblance in normal growth vigor, healthy, fruiting \& flowering of trees behaviors and all trees received the same cultural practices. They were fertilized as recommended by the ministry of agriculture.

Table 1. Physical properties of the experimental soil

\begin{tabular}{|c|c|c|c|c|c|}
\hline \multirow{2}{*}{ Depth } & \multicolumn{4}{|c|}{ Particle size distribution } \\
\cline { 2 - 6 } (cm) & Organic & Sand & Silt & Clay & Soil \\
& matter & $(\%)$ & $(\%)$ & $(\%)$ & Texture \\
\hline $0-30$ & 2.72 & 46.8 & 22.0 & 31.2 & SCL \\
$30-60$ & 2.38 & 48.8 & 22.0 & 29.2 & SCL \\
\hline
\end{tabular}



Nutritional Status of 'Navel Orange' Trees

Table 2. Chemical properties of the experimental soil

\begin{tabular}{|c|c|c|c|c|c|}
\hline \multirow{3}{*}{$\begin{array}{c}\text { Depth } \\
\text { (cm) }\end{array}$} & \multirow{3}{*}{$\mathrm{pH}$} & \multirow{3}{*}{$\underset{\text { milimos/cm }}{\text { E.C }}$} & \multirow{2}{*}{\multicolumn{3}{|c|}{$\begin{array}{c}\text { Saturation soluble ex- } \\
\text { tract }\end{array}$}} \\
\hline & & & & & \\
\hline & & & $\mathrm{Ca}^{++}$ & $\mathrm{Mg}^{++}$ & $\mathrm{Na}^{+}$ \\
\hline $0-30$ & 7.65 & 0.67 & 998 & 164 & 38 \\
\hline $30-60$ & 7.60 & 0.78 & 875 & 175 & 23 \\
\hline \multirow{2}{*}{$\begin{array}{c}\text { Depth } \\
\text { (cm) }\end{array}$} & \multicolumn{2}{|c|}{$\begin{array}{l}\text { Available macronutrients } \\
(\mathrm{mg} / 100 \mathrm{~g})\end{array}$} & \multicolumn{3}{|c|}{$\begin{array}{l}\text { Available micronutrients } \\
\text { (ppm) }\end{array}$} \\
\hline & $\mathbf{P}$ & $\mathrm{K}$ & $\mathrm{Fe}$ & $\mathrm{Zn}$ & $\mathrm{Cu}$ \\
\hline $0-30$ & 1.5 & 23 & 3.6 & 4.4 & 2.5 \\
\hline $30-60$ & 1.4 & 20 & 4.2 & 3.6 & 3.2 \\
\hline
\end{tabular}

The experiment involved three antioxidant materials named salicylic acid, citric acid and folic acid, and spraying by three levels of each of the salicylic, citric and folic acid as follows (250, 500 and 1000 ppm) plus control treatment so the experiment included ten treatments. Selected trees were spraying three times (at the beginning of the growth cycle in March, just after fruit setting in May and just after June drop in July) by aqueous solution of salicylic acid, citric acid and folic acid until the point of runoff with the different level of each one. TritonX1000 at $0.05 \%$ was used as a wetting agent in all treatments. Control treatment was sprayed with tap water + TritonX1000. The experiment was laid out in sample study in a randomized complete block design with 4 replicates and each replicate was represented by one tree. The following characteristics were studied:

\section{Growth Measurements}

- Leaf area: five leaves were taken (one leaf per shoot * five shoots). Leaf area was taken by using model 3100 area meter.

- Specific leaf area: was calculated by equation (leaf area /dry weight) (Peter et al 1999).

- Total chlorophyll content: five leaves were taken (one leaf per shoot * five shoots). Total Chlorophyll content was taken by SPAD - 502 MINOLTA chlorophyll meter.

- Leaves dry matter\%: was calculated by equation (leaves dry weight/ leaves fresh weight)*100.

\section{Yield $(\mathrm{Kg} /$ tree $)$}

- At maturity stage (the end of second week of November), the average number of fruit/ tree was counted. Moreover, five fruits from each replicate were used to obtain the average fruit weight $(\mathrm{g})$. Average fruit weight was determined by weighting a sample of five fruits from each replicate and average fruit weight $(\mathrm{g})$ was calculated. Such average was multiplied by the average number of fruits /tree to obtain the average yield per tree $(\mathrm{Kg})$.

- Fruit set \% was calculated by (No. of total fruit set / No. of flower) ${ }^{\star} 100$. Selected trees were sprayed two weeks after full bloom.

- Fruits drop\% was calculated by ((No. of total fruit set - No. of fruits at last count)/ No. of total fruits set) ${ }^{*} 100$. Selected trees were sprayed two weeks after full bloom and monthly from May till October in both seasons.

\section{Fruit Quality}

- At harvesting time (the end of second week of November) randomly sample of five fruit /tree was collected and determined the following:

\section{Physical and chemical fruit properties}

Fruit volume it was measured by using cylinder. Fruit shape index it was calculated as height/diameter ratio. Juice weight it was measured by using the balance. Juice volume it was measured by using cylinder. 
Peel: fruit\% it was calculated by: (weight of peel/ weight of fruit)*100. Pulp: fruit\% it was calculated by: (weight of pulp/ weight of fruit) ${ }^{\star} 100$. Juice $\%$ it was calculated by: (juice volume/ fruit volume $)^{\star} 100$. Vitamin C "Ascorbic acid content" (mg/100 ml juice) it measured by using $3 \%$ Oxalic acid and 2,6dichlorophenol indophenol was determined according to (A.O.A.C., 1990). Total soluble solids (T.S.S.) it was measured by using Zeiss hand refractometer model HR-110. Total acidity \% it was measured according to (A.O.A.C., 1990) was determined in fruit juice as a percentage of anhydrous citric acid by titration with standard $0.1 \mathrm{~N}$ sodium hydroxide solutions and phenolphthalein $1 \%$ used as an indicator. Total soluble solids /acid ratio was calculated by T.S.S. /acidity ratio.

- Chemical leaf analysis: Total Protein\% it was calculated as ( $\mathrm{N} \%$ in leaf X 6.25) according to (A.O.A.C., 1990). Total phenolic compounds was determined in leaves by the colormetric method of Folin-Denis as described by (Shahidi and Naezk, 1995) was used to determine total phenolic compounds by reading the developed blue color at $725 \mathrm{~nm}$ by using spectrophotometer (UV-visible-160A, Shimadzu). One gram of leaves was macerated in $10-20 \mathrm{ml} 80 \%$ ethanol for at least $24 \mathrm{~h}$ at $0^{\circ} \mathrm{C}$, the alcohol was collected, the remained tissue re-extracted with $10-20 \mathrm{ml} 80 \%$ ethanol about three times. At the end, the collected extract was completed to $100 \mathrm{ml}$ using $80 \%$ ethanol. Leaf mineral content: Leaves were tagged on non-flowering or fruitful branches during April on each tree (Jones and Embleton, 1969) and at September of both studied seasons random leaves sample (twenty leaves) were taken from fully mature spring cycle leaves from the forth to the sixth leaf from the top of the selected shoots, then leaves were oven dried at $70^{\circ} \mathrm{C}$ till a constant weight and were weighted after air dried. Dried leaves sample were taken to digested and them determined leaf mineral content as follows. Nitrogen percentage was determined by Micro-Kjeldahl method according to (Jakson, 1973). Phosphorus percentage according to (Page et al 1982) was determined calorimetrically by spectrophotometer method. Potassium percentage by using flame photometer was determined. Calcium, magnesium, Iron, zinc and manganese were estimated by using Atomic Absorption spectrophotometer.
Statistical Analysis: The data of the study were under go to proper statistical analysis of variance according to (Snedecor and Cochran, 1980). Means were differentiated by using Duncan's multiple range test at $5 \%$ confidence (Duncan, 1955). Data were statistically analyzed by the analysis of variance adopting a SPSS package.

\section{RESULTS AND DISCUSSION}

Effect of spraying with some antioxidant compounds on some vegetative growth parameters: Results in Table (3) show the effect of antioxidants spraying on leaf area, specific leaf area, total chlorophyll content and leaf dry matter\%. Data revealed that, leaf area was significantly affected by different levels of antioxidants spraying in both seasons. The least significant values were obtained by $T_{10}$ (control) in the two seasons. With respect to the salicylic acid levels, leaf area was increased gradually by increasing salicylic acid level up to $1000 \mathrm{ppm}$ in the two seasons but without any significant different all among treatments. Regarding to citric acid levels, the first level of citric acid $\left(T_{4}\right)$ gave the least value of leaf area. Other levels from citric acid gave more or less similar values from the same statistical stand point. Generally, leaf area was increased by increasing folic acid level up to $1000 \mathrm{ppm}$ in the two growing season. From all above levels of the three antioxidants materials it seems that, $\mathrm{T}_{5}$ (citric acid at 500 ppm) gave the higher values of leaf area than other all treatments in the two seasons.

In respect to the effect of antioxidants on specific leaf area, data revealed that, specific leaf area was significantly affected with different levels of antioxidants spraying in the two seasons. The least significant values of specific leaf area were obtained by $\mathrm{T}_{10}$ (control) in the two seasons. Spraying with different levels of salicylic acid gave more or less similar values with lack significance difference among them. Specific leaf area was increased gradually by increasing citric acid level up to $1000 \mathrm{ppm}$ in both seasons. The least values of specific leaf area were obtained by the low level of folic acid (250 ppm) whereas other two levels (500 and 1000 ppm) gave more or less similar values. So, it seems that spraying by citric acid at 1000 

Nutritional Status of 'Navel Orange' Trees

ppm gave the highest value of specific leaf area compared with all other treatments in the two growing seasons.

The increasing in leaf area and specific leaf area under application various levels of salicylic acid, citric acid and folic could be explained by their effect in enhancing division and enlargement of cells (Abada, 2014).

Total chlorophyll content was significantly affected by spraying with different levels of antioxidants in both seasons. The least significant values of total chlorophyll content were taken by $T_{10}$ (control) in the two seasons. Regarding to salicylic acid levels, total chlorophyll content increased by increasing salicylic acid level up to 500 ppm and 1000 ppm in the first and second seasons, respectively. Total chlorophyll content increased gradually by increasing citric acid level up to 1000 and $500 \mathrm{ppm}$ in the first and second seasons, respectively without any significant different among them. The first level of folic acid $\left(T_{7}\right)$ gave the least values of total chlorophyll. Other folic acid levels gave more or less similar values with the same statistical stand point. So, it seems that the highest values of chlorophyll content were recorded by $\mathrm{T}_{2}(500$ ppm salicylic acid) and $T_{8}$ (500 ppm folic acid) in the two seasons.

Regarding to leaf dry matter percentage, in both seasons all levels of salicylic acid improved dry matter. The least values of dry matter were obtained by $\mathrm{T}_{4}$ and $\mathrm{T}_{5}$. On the other hand, treated with T3 (1000 ppm salicylic acid) led to highest dry matter in the two seasons. Otherwise, the first level of folic acid was more affected on dry matter\% compared with other folic acid levels. The highest values of dry matter\% were recorded with $\mathrm{T}_{3}$ (1000 ppm salicylic acid) in the both season.

From the above results It is clear that, vegetative growth parameters of Navel orange trees were significantly increased by $\mathrm{T}_{2}$ (500 ppm salicylic acid), $\mathrm{T}_{6}$ (1000 ppm citric acid) and $T_{8}$ (500 ppm folic acid) through the two seasons. Otherwise, in most cases $T_{6}$ gave the highest vales of all vegetative growth parameters.

The presented results had agreement with these found by El-Badawy, (2013) on "Canino" apricot trees, Abdel Aal and OrabyMona, (2013) on mango cv. "Alphonse" seedlings, Ahmed et al (2013) on "Hindy bisinnara" mango trees and Mohamed (2014) on
"Thompson seedless" grapevines, and they pointed out that antioxidants were very effective in enhancing vegetative growth.

Salicylic acid, citric acid and folic acid have several influences on trees such as enhancing the biosynthesis of plant pigments, increasing photosynthetic pigment which reflected on photosynthesis process (Ibrahim et al 2015). The beneficial effect of citric acid on photosynthetic pigments may be due to its role on increasing the rates of photochemical reduction (Kumar et al 1988), chloroplast structure, photosynthetic electron transfers as well as photosynthesis (El-Shazly et al 2013).

Effect of spraying with some antioxidant materials on fruit drop \%: Results in Table (4) show the effect of antioxidants spraying on fruit drop \%. Data revealed that, fruit drop\% was significantly affected by spraying with three antioxidant materials in the two seasons. Results indicated that, fruit drop\% were decreased significantly by $\mathrm{T}_{2}(500 \mathrm{ppm}$ salicylic acid), $T_{5}\left(500 \mathrm{ppm}\right.$ citric acid) and $T_{7}$ (250 ppm folic acid) in the end of each season (October).

Effect of spraying with some antioxidant materials on fruit set \%, fruit weight, fruit number and yield: Results in Table (5) show the effect of antioxidants spraying on fruit set\%, fruit weight, fruit number and yield. Data revealed that, all characters were significantly affected by foliar application of three antioxidant materials in at all their levels in both seasons. Untreated trees (control) gave the least values of fruit set\% in both seasons. The second level from salicylic acid (500 ppm) and citric acid (500 ppm) gave the highest values of fruit set\% in the two studied seasons compared with other levels of salicylic and citric acid. Regarding to folic acid levels fruit set\% was increased by increasing folic acid level but by lack significance differences among them. Consequently, it could be concluded that, the highest values of fruit set $\%$ were obtained by $T_{2}, T_{5}$ and $T_{9}$. From present results it seems that, spraying by $\mathrm{T}_{2}$ (500 ppm salicylic acid) gave the highest value of fruit set percentage compared with all others treatments in both the two seasons. 
Table 3. Effect of spraying some antioxidants on leaf area, specific leaf area, total chlorophyll content and dry matter percentage of Navel orange trees in 2016 and 2017 seasons.

\begin{tabular}{|c|c|c|c|c|c|c|c|c|}
\hline \multirow[t]{2}{*}{ Treatments } & $\begin{array}{l}\text { Leaf } \\
\text { area } \\
\left(\mathrm{cm}^{2}\right)\end{array}$ & $\begin{array}{l}\text { Specific } \\
\text { leaf area } \\
\left(\mathrm{mm}^{2} / \mathrm{mg}\right)\end{array}$ & $\begin{array}{c}\text { Total } \\
\text { Chlorophyll } \\
\text { content } \\
\text { (SPAD) }\end{array}$ & $\begin{array}{c}\text { Leaf } \\
\text { dry } \\
\text { matter } \\
(\%)\end{array}$ & $\begin{array}{l}\text { Leaf } \\
\text { area } \\
\left(\mathrm{cm}^{2}\right)\end{array}$ & $\begin{array}{c}\text { Specific } \\
\text { leaf area } \\
\left(\mathrm{mm}^{2} / \mathrm{mg}\right)\end{array}$ & \begin{tabular}{|c|} 
Total \\
Chlorophyll \\
content \\
(SPAD)
\end{tabular} & $\begin{array}{c}\text { Leaf } \\
\text { dry } \\
\text { matter } \\
(\%)\end{array}$ \\
\hline & \multicolumn{4}{|c|}{ Season 2016} & \multicolumn{4}{|c|}{ Season 2017} \\
\hline $\begin{array}{r}\mathrm{T}_{1} \text { :Salicyl } \\
250 \mathrm{pp}\end{array}$ & $861 d$ & $.2 \mathrm{~cd}$ & $83.9 \mathrm{c}$ & $40.7 \mathrm{a}$ & $72.7 \mathrm{c}$ & $6 \mathrm{~cd}$ & $84.0 \mathrm{c}$ & $39.5 \mathrm{~b}$ \\
\hline $\begin{array}{c}\mathrm{T}_{2} \text { :Salicylic acid } \\
500 \mathrm{ppm}\end{array}$ & $103.5 \mathrm{~cd}$ & cde & $86.3 a b$ & $38.1 \mathrm{ab}$ & $84.7 \mathrm{c}$ & $4.2 \mathrm{bc}$ & $87.3 \mathrm{ab}$ & $40.7 \mathrm{~b}$ \\
\hline $\begin{array}{r}\text { T3 :Salic } \\
1000\end{array}$ & $114.2 \mathrm{~cd}$ & $9.7 \mathrm{de}$ & 85.2 bc & $40.7 \mathrm{a}$ & $88.4 \mathrm{c}$ & $3.7 \mathrm{~cd}$ & $87.8 \mathrm{a}$ & $43.5 \mathrm{a}$ \\
\hline $\begin{array}{c}\mathrm{T}_{4}: \text { : Citric acid } \\
\text { 250ppm }\end{array}$ & 123.7 b & 10.7 cde & $85.4 \mathrm{~b}$ & $33.0 \mathrm{~d}$ & 88.9 a & $4.1 \mathrm{bc}$ & $86.7 \mathrm{ab}$ & $25.5 \mathrm{e}$ \\
\hline $\begin{array}{c}\mathrm{T}_{5} \text { :Citric acid } \\
\text { 500ppm }\end{array}$ & $128.5 \mathrm{a}$ & $12.2 \mathrm{bc}$ & $85.0 \mathrm{bc}$ & $33.2 \mathrm{~d}$ & $94.4 \mathrm{a}$ & $4.4 \mathrm{bc}$ & $87.8 \mathrm{a}$ & $25.6 \mathrm{e}$ \\
\hline $\begin{array}{l}\mathrm{T}_{6}: \text { Citric acid } \\
\text { 1000ppm }\end{array}$ & 128. & $.0 \mathrm{a}$ & $86.4 a b$ & $37.2 \mathrm{ab}$ & $95.0 \mathrm{a}$ & $6.8 \mathrm{a}$ & $87.0 \mathrm{ab}$ & $36.5 \mathrm{c}$ \\
\hline $\begin{array}{c}\mathrm{T}_{7} \text { :Folic acid } \\
\text { 250ppm }\end{array}$ & $127.6 \mathrm{~cd}$ & $9.5 \mathrm{de}$ & $85.5 b$ & $37.9 \mathrm{ab}$ & $93.3 \mathrm{c}$ & $3.6 \mathrm{~cd}$ & $85.2 b c$ & $35.3 \mathrm{c}$ \\
\hline $\begin{array}{c}\mathrm{T}_{8}: \text { Folic acid } \\
500 \mathrm{ppm}\end{array}$ & $129.8 \mathrm{c}$ & $13.6 \mathrm{~b}$ & $87.2 \mathrm{a}$ & $33.1 \mathrm{~d}$ & $97.8 \mathrm{a}$ & $4.9 \mathrm{~b}$ & $86.1 \mathrm{ab}$ & $34.2 \mathrm{~cd}$ \\
\hline $\begin{array}{c}T_{9} \text { :Folic acid } \\
\text { 1000ppm }\end{array}$ & $131.3 b$ & $12.8 b c$ & $86.2 \mathrm{ab}$ & $33.2 \mathrm{~d}$ & $93.6 \mathrm{~b}$ & $4.9 \mathrm{~b}$ & 85.9abc & $32.3 \mathrm{~d}$ \\
\hline $\mathrm{T}_{10}$ :Control & $83.5 \mathrm{e}$ & $9.1 \mathrm{e}$ & $75.1 \mathrm{~d}$ & $36.7 \mathrm{c}$ & $63.8 \mathrm{~d}$ & $3.2 \mathrm{~d}$ & $79.0 \mathrm{~d}$ & $36.8 \mathrm{c}$ \\
\hline
\end{tabular}

Values having the same letter(s) in the same column in each season are not significant by Duncan's multiple range test, $5 \%$ level.

Table 4. Effect of spraying with some antioxidants on fruit drop percentage of Navel orange trees in 2016 and 2017 seasons

\begin{tabular}{|c|c|c|c|c|c|c|c|c|c|c|c|c|}
\hline \multirow[t]{2}{*}{ Treatments } & $\begin{array}{l}\text { May } \\
(\%)\end{array}$ & $\begin{array}{l}\text { Jun. } \\
(\%)\end{array}$ & $\begin{array}{l}\text { Jul. } \\
\text { (\%) }\end{array}$ & $\begin{array}{l}\text { Aug. } \\
(\%)\end{array}$ & $\begin{array}{c}\text { Sept. } \\
(\%)\end{array}$ & $\begin{array}{l}\text { Oct. } \\
\text { (\%) }\end{array}$ & $\begin{array}{c}\text { May } \\
(\%)\end{array}$ & \begin{tabular}{|l|} 
Jun. \\
(\%)
\end{tabular} & $\begin{array}{l}\text { Jul. } \\
\text { (\%) }\end{array}$ & $\begin{array}{l}\text { Aug. } \\
(\%)\end{array}$ & \begin{tabular}{|c|} 
Sept. \\
$(\%)$
\end{tabular} & $\begin{array}{l}\text { Oct. } \\
\text { (\%) }\end{array}$ \\
\hline & \multicolumn{6}{|c|}{ Season 2016} & \multicolumn{6}{|c|}{ Season 2017} \\
\hline $\begin{array}{c}\mathrm{T}_{1}: \text { Salicylic acid } \\
\text { 250ppm }\end{array}$ & $0.0 \mathrm{a}$ & $11.1 \mathrm{a}$ & 24.1abc & $24.1 \mathrm{abc}$ & $27.6 \mathrm{bc}$ & $31.1 \mathrm{~b}$ & $0.0 \mathrm{a}$ & $4.4 a b$ & $17.3 b$ & $17.3 b$ & $20.1 b$ & $26.0 \mathrm{~b}$ \\
\hline $\begin{array}{c}\mathrm{T}_{2}: \text { Salicylic acid } \\
\text { 500ppm }\end{array}$ & $0.0 a$ & $0.0 \mathrm{c}$ & $7.5 d$ & $7.5 d$ & $9.6 d$ & $12.8 c$ & $0.0 \mathrm{a}$ & $0.0 c$ & $6.4 \mathrm{c}$ & $6.4 \mathrm{c}$ & $8.2 \mathrm{c}$ & $11.0 \mathrm{c}$ \\
\hline $\begin{array}{c}\text { T3 :Salicylic acid } \\
\text { 1000ppm }\end{array}$ & $0.0 \mathrm{a}$ & $2.8 \mathrm{bc}$ & $18.7 \mathrm{bcd}$ & 18.7bcd & $23.3 b c$ & $29.5 b$ & $0.0 \mathrm{a}$ & $3.6 b$ & $17.5 b$ & $17.5 b$ & $23.3 b$ & $29.2 b$ \\
\hline $\begin{array}{l}\mathrm{T}_{4}: \text { Citric acid } \\
\text { 250ppm }\end{array}$ & $0.0 \mathrm{a}$ & $2.8 \mathrm{bc}$ & $21.4 a b c$ & $21.4 \mathrm{abc}$ & $26.6 \mathrm{bc}$ & $29.3 b$ & $0.0 \mathrm{a}$ & $1.7 \mathrm{c}$ & $18.4 b$ & $18.4 b$ & $24.5 \mathrm{~b}$ & $31.1 b$ \\
\hline $\begin{array}{c}\mathrm{T}_{5}: \text { Citric acid } \\
\text { 500ppm }\end{array}$ & $0.0 \mathrm{a}$ & $2.7 \mathrm{bc}$ & $14.0 \mathrm{~cd}$ & $14.0 \mathrm{~cd}$ & $18.3 \mathrm{~cd}$ & $21.4 \mathrm{bc}$ & $0.0 \mathrm{a}$ & $6.8 \mathrm{a}$ & $13.7 \mathrm{bc}$ & $13.7 \mathrm{bc}$ & $18.2 b$ & $21.6 b c$ \\
\hline $\begin{array}{c}\mathrm{T}_{6}: \text { Citric acid } \\
\text { 1000ppm }\end{array}$ & $0.0 \mathrm{a}$ & $6.7 \mathrm{abc}$ & $33.6 \mathrm{a}$ & $33.6 \mathrm{a}$ & $40.0 a$ & $46.3 a$ & $0.0 \mathrm{a}$ & $5.8 \mathrm{ab}$ & $32.3 a$ & $32.3 a$ & $41.2 \mathrm{a}$ & $47.2 \mathrm{a}$ \\
\hline $\begin{array}{l}\mathrm{T}_{7} \text { :Folic acid } \\
250 \mathrm{ppm}\end{array}$ & $0.0 \mathrm{a}$ & $3.3 b c$ & $15.2 \mathrm{~cd}$ & $15.2 \mathrm{~cd}$ & $17.0 \mathrm{~cd}$ & $23.9 \mathrm{bc}$ & $0.0 \mathrm{a}$ & $4.3 a b$ & $15.2 \mathrm{bc}$ & $15.2 \mathrm{bc}$ & $20.3 b$ & $24.9 b$ \\
\hline $\begin{array}{c}\mathrm{T}_{8} \text { :Folic acid } \\
500 \mathrm{ppm}\end{array}$ & $0.0 \mathrm{a}$ & $8.1 \mathrm{ab}$ & 22.3abc & 26.9abc & $28.0 \mathrm{bc}$ & $30.4 b$ & $0.0 \mathrm{a}$ & $2.5 \mathrm{bc}$ & $16.3 \mathrm{bc}$ & $17.4 b$ & $17.4 \mathrm{~b}$ & $27.5 b$ \\
\hline $\begin{array}{l}\mathrm{T}_{9} \text { :Folic acid } \\
\text { 1000ppm }\end{array}$ & $0.0 \mathrm{a}$ & $4.0 \mathrm{abc}$ & $18.9 \mathrm{bcd}$ & 18.9bcd & $18.9 \mathrm{~cd}$ & $25.5 b$ & $0.0 \mathrm{a}$ & $5.5 a b$ & $18.8 b$ & $18.8 b$ & $24.5 \mathrm{~b}$ & $31.7 \mathrm{~b}$ \\
\hline $\mathrm{T}_{10}$ :Control & $0.0 \mathrm{a}$ & $4.1 \mathrm{abc}$ & $29.6 a b$ & $29.6 a b$ & $33.7 a b$ & $42.9 a$ & $0.0 \mathrm{a}$ & $4.8 a b$ & $30.3 a$ & $30.3 a$ & $40.1 \mathrm{a}$ & $47.4 \mathrm{a}$ \\
\hline
\end{tabular}

Values having the same letter(s) in the same column in each season are not significant by Duncan's multiple range test, $5 \%$ level. 

Nutritional Status of 'Navel Orange' Trees

Table 5. Effect of spraying with some antioxidants on fruit set, fruit weight, fruit number and yield of Navel orange trees in 2016 and 2017 seasons

\begin{tabular}{|c|c|c|c|c|c|c|c|c|}
\hline \multirow[t]{2}{*}{ Treatments } & $\begin{array}{l}\text { Fruit } \\
\text { Set (\%) }\end{array}$ & $\begin{array}{c}\text { Fruit } \\
\text { Weight } \\
\text { (g) }\end{array}$ & $\begin{array}{c}\text { Fruit } \\
\text { No./tree }\end{array}$ & $\begin{array}{c}\text { Yield/ tree } \\
(\mathrm{kg})\end{array}$ & $\begin{array}{l}\text { Fruit } \\
\text { Set (\%) }\end{array}$ & $\begin{array}{c}\text { Fruit } \\
\text { Weight } \\
\text { (g) }\end{array}$ & $\begin{array}{c}\text { Fruit } \\
\text { No./tree }\end{array}$ & $\begin{array}{c}\text { Yield/tree } \\
(\mathbf{k g})\end{array}$ \\
\hline & \multicolumn{4}{|c|}{ Season 2016} & \multicolumn{4}{|c|}{ Season 2017} \\
\hline $\begin{array}{c}\mathrm{T}_{1} \text { :Salicylic acid } \\
\text { 250ppm }\end{array}$ & $0.6 \mathrm{de}$ & $257.3 \mathrm{bc}$ & $103.0 \mathrm{~cd}$ & $26.5 \mathrm{c}$ & 0.7 cde & $253.9 c$ & $123.0 \mathrm{~cd}$ & $31.2 \mathrm{c}$ \\
\hline $\begin{array}{c}\mathrm{T}_{2}: \text { Salicylic acid } \\
\text { 500ppm }\end{array}$ & $1.5 \mathrm{a}$ & 299.2 a & $119.0 \mathrm{a}$ & $35.6 \mathrm{a}$ & $1.6 \mathrm{a}$ & $299.1 \mathrm{a}$ & $137.0 \mathrm{ab}$ & $40.0 \mathrm{a}$ \\
\hline $\begin{array}{c}\text { T3 :Salicylic acid } \\
\text { 1000ppm }\end{array}$ & $0.6 \mathrm{de}$ & 263.9 b & $90.0 \mathrm{e}$ & $23.8 d$ & 0.7 cde & $245.6 \mathrm{c}$ & 127.0bcd & $31.2 \mathrm{c}$ \\
\hline $\begin{array}{c}\mathrm{T}_{4}: \text { : Citric acid } \\
\text { 250ppm }\end{array}$ & $0.5 \mathrm{e}$ & $223.9 \mathrm{de}$ & $75.0 \mathrm{~g}$ & $16.8 \mathrm{e}$ & $0.6 \mathrm{~d}$ ef & $222.9 d$ & $118.0 \mathrm{~d}$ & $26.3 d$ \\
\hline $\begin{array}{c}\mathrm{T}_{5}: \text { Citric acid } \\
500 \mathrm{ppm}\end{array}$ & $1.3 a b$ & $275.9 \mathrm{~b}$ & $114.0 \mathrm{ab}$ & $31.5 b$ & $1.4 \mathrm{a}$ & $275.1 b$ & $141.0 \mathrm{a}$ & $38.8 \mathrm{a}$ \\
\hline $\begin{array}{c}\mathrm{T}_{6}: \text { Citric acid } \\
\text { 1000ppm }\end{array}$ & $0.4 \mathrm{e}$ & 205.9 e & $54.0 \mathrm{~h}$ & $11.1 \mathrm{~g}$ & $0.4 \mathrm{df}$ & $225.9 d$ & $67.0 \mathrm{f}$ & $15.1 \mathrm{f}$ \\
\hline $\begin{array}{l}\mathrm{T}_{7} \text { :Folic acid } \\
\text { 250ppm }\end{array}$ & $0.8 \mathrm{~cd}$ & $311.4 \mathrm{a}$ & $98.0 \mathrm{~d}$ & $30.5 b$ & $0.8 \mathrm{bcd}$ & $296.0 \mathrm{a}$ & $123.0 \mathrm{~cd}$ & $36.4 \mathrm{~b}$ \\
\hline $\begin{array}{c}\mathrm{T}_{8} \text { :Folic acid } \\
500 \mathrm{ppm}\end{array}$ & $1.0 \mathrm{c}$ & $242.2 \mathrm{~cd}$ & $109.0 \mathrm{bc}$ & $26.4 \mathrm{c}$ & $1.0 \mathrm{~b}$ & $244.6 \mathrm{c}$ & $136.0 \mathrm{~b}$ & $33.3 b c$ \\
\hline $\begin{array}{l}\text { T9:Folic acid } \\
\text { 1000ppm }\end{array}$ & $1.1 \mathrm{bc}$ & $256.2 \mathrm{bc}$ & $104.0 \mathrm{~cd}$ & $26.7 \mathrm{c}$ & $0.9 \mathrm{bc}$ & $242.8 \mathrm{c}$ & $133.0 \mathrm{bc}$ & $32.3 \mathrm{c}$ \\
\hline $\mathrm{T}_{10}$ :Control & $0.3 \mathrm{e}$ & $171.8 \mathrm{f}$ & $83.0 \mathrm{f}$ & $14.3 \mathrm{f}$ & $0.4 \mathrm{f}$ & $183.3 \mathrm{e}$ & $123.0 \mathrm{e}$ & $22.6 \mathrm{e}$ \\
\hline
\end{tabular}

Values having the same letter(s) in the same column in each season are not significant by Duncan's multiple range test, $5 \%$ level.

Regarding to the effect of antioxidant materials on fruit weight, data revealed that, the least significant values were obtained by $T_{10}$ in the two seasons. The second level of from both of salicylic acid $\left(T_{2}\right)$ gave the higher values of fruit weight in the two seasons than other levels of salicylic and citric acid. The lowest level of folic acid gave higher values of fruit weight than other levels. So from the present results it could be concluded that, spraying by $T_{7}$ (250 ppm folic acid) and $T_{2}$ (500 ppm salicylic acid) gave the highest values of fruit weight in the two seasons.

Data revealed that, untreated trees gave the lowest fruit number/tree in the two seasons. The second level of salicylic acid $\left(T_{2}\right)$ and citric acid gave the higher values of fruit number /tree in the two seasons than other levels of each antioxidant materials. In general, spraying with $T_{2}$ (500 ppm salicylic acid) and $T_{5}$ (500 ppm citric acid) gave the highest values of fruit number/tree in the two seasons.
Data revealed that, the least values of yield were obtained by $\mathrm{T}_{10}$ (control) in the two seasons. The second level of from salicylic acid $\left(T_{2}\right)$ gave the highest values of yield in both seasons compared with the other levels of all antioxidant treatments. The first level of folic acid (250 ppm) gave higher values of yield than other folic acid levels in the two seasons. From presented results it could be observed that, spraying by $\mathrm{T}_{2}(500 \mathrm{ppm}$ salicylic acid) in the first season or $\mathrm{T}_{2}(500 \mathrm{ppm}$ salicylic acid) and $T_{5}(500 \mathrm{ppm}$ citric acid) in the second season gave the highest values of yield.

It is clear that yield and his parameters were significantly increased by $\mathrm{T}_{2}(500 \mathrm{ppm}$ salicylic acid), $T_{5}$ (500 ppm citric acid) and $T_{7}$ (250 ppm folic acid) through the two seasons. In most cases $\mathrm{T}_{2}$ (500 ppm salicylic acid) was the superior treatment for all yield parameters. 
These results are in agreement with those obtained by (Emam et al 2011) on flax plant, (Abdou et al 2011) on clove basil and (Mansour et al 2011) on "Anna" apple orchards, they found that the foliar application of antioxidant materials such as salicylic, citric and folic acid was very effective in improving yield of several different plants. Salicylic acid and folic acid play a definite role in solving the problem of poor yielding through enhancing growth, nutritional statues, yield in different evergreen fruit crops (Prusky, 1988) on avocado fruits and (Ahmed et al 2007) on "Sewy" date palms thus enhancing growth, nutritional states and yield quantitatively and qualitatively and (Roshdy et al 2011) on "Williams" banana. Citric acid playing an important role in plant metabolism that led to enhancing fruit set, fruit retention, number of fruit per tree and yield(Ahmed and Abdelaal, 2007) on "Anna" apple, (Mansour et al 2008) on pear "Le- Conte" and (Singh et al 2010) on cucumber "Cucum is sativa L."

Effect of spraying with some antioxidant materials on fruit physical properties: Results in Table (6) show the effect of antioxidants spraying on fruit volume, fruit shape index, juice weight and juice volume. Data revealed that, fruit volume, juice weight and juice volume were significantly affected by spraying various levels of antioxidant materials in both seasons. The lowest significant values of fruit volume were obtained by $T_{10}$ (control) in the two seasons. All levels of salicylic acid gave significant affected on fruit volume without any significant different between the three levels in the two seasons. Regarding to citric acid levels, $T_{5}$ gave the higher significant values of fruit volume than the first and third levels especially in the first season. The third level of folic acid $\left(T_{9}\right)$ gave the least values of fruit volume. On the other hand, the first level of folic acid $\left(T_{7}\right)$ gave the highest values of fruit volume in both growing season. In general, $\mathrm{T}_{7}$ (250 ppm folic acid) gave the highest significant values of fruit volume.

Regarding to fruit shape index, all treatments gave more or less like values with the same statistically stand point. Especially in the second season where data showed insignificant differences among treatments.

The least significant values of juice weight were obtained by control treatment in the two growing seasons. By increasing salicylic and citric acid levels up to $500 \mathrm{ppm}\left(\mathrm{T}_{2}\right.$ and $\left.T_{5}\right)$ juice weight in- creased in the two seasons. Regarding to folic acid levels, $T_{7}$ and $T_{8}$ gave the highest significant values of juice weight without any significant difference between $T_{7}$ and $T_{8}$ in the two seasons. In general, $\mathrm{T}_{2}$ (500 ppm salicylic acid) gave the highest values of juice weight.

With respect to juice volume, control treatment $\left(T_{10}\right)$ gave the least significant values of juice volume in the two growing seasons. On the other hand, the first level of salicylic acid gave the highest significant values of juice volume in the two seasons. Concerning to citric acid levels, juice volume was increased by increasing citric acid levels up to $500 \mathrm{ppm}$ in the growing seasons. The first level of folic acid gave the highest significant values of juice volume in the two seasons. Generally, the first level of salicylic acid (250 ppm) gave the highest value of juice volume.

Effect of spraying with some antioxidant materials on fruit physical properties percentage: Results in Table (7) show the effect of antioxidants spraying on peel: fruit $\%$, pulp: fruit $\%$ and juice $\%$. Data revealed that, peel: fruit\%, pulp: fruit $\%$ and juice\% were significantly affected by different levels of antioxidants treatments in both growing season. The highest values of peel: fruit\% were obtained by $T_{10}$ (control) in the two seasons. The second level of salicylic acid $\left(T_{2}\right)$ gave the least values of peel: fruit\% compared with other levels of salicylic acid. The first level of citric acid $\left(T_{4}\right)$ gave the least values of peel: fruit\% in the first season whereas, in the second season $\mathrm{T}_{5}$ gave least values of peel: fruit\%. The third level of folic acid $\left(T_{9}\right)$ gave the least values of peel: fruit\% in first season, whereas in second season $\mathrm{T}_{7}$ gave least values of peel: fruit\% without insignificant difference between $\mathrm{T}_{7}$ and $\mathrm{T}_{9}$. In general, the least significant values of peel: fruit \% was obtained by spraying with $\mathrm{T}_{2}$ (salicylic acid at $500 \mathrm{ppm}$ ).

In respect to pulp: fruit\%, the least significant values of pulp: fruit\% were obtained by control in the two seasons. Regarding to salicylic acid levels, the highest values of pulp: fruit\% was given by $T_{2}$ in both growing seasons. The first and second levels of citric acid ( $T_{4}$ and $\left.T_{5}\right)$ gave the higher values of pulp: fruit\% in first and second seasons, respectively. In respect to levels of folic acid, pulp: fruit\% increased by $T_{9}$ in both seasons. In general, the second level of salicylic acid (500 ppm) gave the highest values of pulp: fruit\%. 
Table 6. Effect of spraying with some antioxidants on some fruit physical properties of Navel orange trees in 2016 and 2017 seasons

\begin{tabular}{|c|c|c|c|c|c|c|c|c|}
\hline \multirow[t]{2}{*}{ Treatments } & $\begin{array}{c}\begin{array}{c}\text { Fruit } \\
\text { volume } \\
(\mathrm{ml})\end{array} \\
\end{array}$ & $\begin{array}{c}\text { Fruit } \\
\text { shape } \\
\text { index }\end{array}$ & $\begin{array}{l}\text { Juice } \\
\text { weight } \\
\text { (g) }\end{array}$ & $\begin{array}{c}\text { Juice } \\
\text { volume } \\
\text { (g) }\end{array}$ & $\begin{array}{c}\begin{array}{c}\text { Fruit } \\
\text { volume } \\
(\mathrm{ml})\end{array} \\
\end{array}$ & \begin{tabular}{|c|} 
Fruit \\
shape \\
index \\
\end{tabular} & $\begin{array}{c}\text { Juice } \\
\text { weight } \\
\text { (g) }\end{array}$ & $\begin{array}{l}\text { Juice } \\
\text { volume } \\
\text { (g) }\end{array}$ \\
\hline & \multicolumn{4}{|c|}{ Season 2016} & \multicolumn{4}{|c|}{ Season 2017} \\
\hline $\begin{array}{c}\mathrm{T}_{1} \text { : Salicylic acid } \\
\text { 250ppm }\end{array}$ & $280.0 \mathrm{ab}$ & $1.1 \mathrm{ab}$ & $120.0 \mathrm{~b}$ & $145.0 \mathrm{a}$ & $380.0 \mathrm{bc}$ & $1.0 \mathrm{ab}$ & $120.0 \mathrm{c}$ & $165.5 \mathrm{a}$ \\
\hline $\begin{array}{c}\mathrm{T}_{2}: \text { Salicylic acid } \\
500 \mathrm{ppm}\end{array}$ & $262.5 b c$ & $1.1 \mathrm{ab}$ & $130.0 \mathrm{a}$ & $135.5 \mathrm{bc}$ & $377.5 \mathrm{bc}$ & $1.0 \mathrm{ab}$ & $140.0 \mathrm{a}$ & $151.5 \mathrm{bcd}$ \\
\hline $\begin{array}{c}\text { T3 }: \text { Salicylic acid } \\
\text { 1000ppm }\end{array}$ & $275.0 \mathrm{ab}$ & $1.1 \mathrm{ab}$ & $110.0 \mathrm{c}$ & $131.0 \mathrm{~cd}$ & $387.5 b$ & $1.1 \mathrm{a}$ & $120.0 \mathrm{c}$ & 149.3 cde \\
\hline $\begin{array}{l}\mathrm{T}_{4}: \text { : Citric acid } \\
\text { 250ppm }\end{array}$ & $262.5 b c$ & $1.0 \mathrm{~b}$ & $110.0 \mathrm{c}$ & $125.5 \mathrm{~d}$ & $347.5 \mathrm{~cd}$ & $1.1 \mathrm{a}$ & $110.0 \mathrm{~d}$ & $143.3 \mathrm{e}$ \\
\hline $\begin{array}{c}\mathrm{T}_{5}: \text { Citric acid } \\
\text { 500ppm }\end{array}$ & $285.0 \mathrm{a}$ & $1.1 \mathrm{ab}$ & $120.0 \mathrm{~b}$ & $135.0 \mathrm{bc}$ & $405.0 \mathrm{~b}$ & $1.0 \mathrm{ab}$ & $120.0 \mathrm{c}$ & $154.0 \mathrm{bc}$ \\
\hline $\begin{array}{c}\mathrm{T}_{6}: \text { Citric acid } \\
\text { 1000ppm }\end{array}$ & $207.5 d$ & $1.0 \mathrm{~b}$ & $110.0 \mathrm{c}$ & $93.5 \mathrm{f}$ & $337.5 \mathrm{~d}$ & $1.0 \mathrm{ab}$ & $110.0 \mathrm{~d}$ & $98.3 \mathrm{f}$ \\
\hline $\begin{array}{c}\mathrm{T}_{7}: \text { Folic acid } \\
\text { 250ppm }\end{array}$ & $270.0 \mathrm{ab}$ & $1.0 \mathrm{~b}$ & $130.0 \mathrm{a}$ & $140.0 \mathrm{~b}$ & $442.5 \mathrm{a}$ & $1.0 \mathrm{ab}$ & $130.0 \mathrm{~b}$ & $158.0 \mathrm{~b}$ \\
\hline $\begin{array}{l}\mathrm{T}_{8} \text { :Folic acid } \\
500 \mathrm{ppm}\end{array}$ & $247.5 \mathrm{c}$ & $1.1 \mathrm{ab}$ & $130.0 \mathrm{a}$ & $115.5 \mathrm{e}$ & $372.5 \mathrm{bcd}$ & $1.0 \mathrm{ab}$ & $130.0 \mathrm{~b}$ & $146.8 \mathrm{cde}$ \\
\hline $\begin{array}{l}\mathrm{T}_{9}: \text { Folic acid } \\
\text { 1000ppm }\end{array}$ & $260.5 b c$ & $1.1 \mathrm{ab}$ & $120.0 \mathrm{~b}$ & $127.5 \mathrm{~cd}$ & $370.0 \mathrm{bcd}$ & $1.0 \mathrm{ab}$ & $120.0 \mathrm{c}$ & $144.5 \mathrm{de}$ \\
\hline $\mathrm{T}_{10}$ :Control & $165.0 \mathrm{e}$ & $1.2 \mathrm{a}$ & $60.0 \mathrm{~d}$ & $77.3 \mathrm{~g}$ & $252.5 \mathrm{e}$ & $1.1 \mathrm{a}$ & $60.0 \mathrm{e}$ & $97.3 \mathrm{f}$ \\
\hline
\end{tabular}

Values having the same letter(s) in the same column in each season are not significant by Duncan's multiple range test, $5 \%$ level.

Table 7. Effect of spraying with some antioxidants on some fruit physical properties percentage of Navel orange trees in 2016 and 2017 seasons

\begin{tabular}{|c|c|c|c|c|c|c|}
\hline \multirow[b]{2}{*}{ Treatments } & \multicolumn{2}{|c|}{ Peel : fruit (\%) } & \multicolumn{2}{|c|}{ Pulp : fruit (\%) } & \multicolumn{2}{|c|}{ Juice (\%) } \\
\hline & $\begin{array}{c}\text { Season } \\
2016\end{array}$ & $\begin{array}{c}\text { Season } \\
2017\end{array}$ & $\begin{array}{c}\text { Season } \\
2016\end{array}$ & $\begin{array}{c}\text { Season } \\
2017\end{array}$ & $\begin{array}{c}\text { Season } \\
2016\end{array}$ & $\begin{array}{c}\text { Season } \\
2017\end{array}$ \\
\hline $\begin{array}{c}\mathrm{T}_{1} \text { :Salicylic acid } \\
250 \mathrm{ppm}\end{array}$ & $1.8 \mathrm{bc}$ & $3.3 \mathrm{c}$ & $98.2 \mathrm{e}$ & $96.7 \mathrm{~cd}$ & $51.8 \mathrm{a}$ & $43.6 \mathrm{a}$ \\
\hline $\begin{array}{c}\mathrm{T}_{2} \text { :Salicylic acid } \\
500 p p m\end{array}$ & $1.0 \mathrm{~h}$ & $2.4 \mathrm{f}$ & $99.0 \mathrm{a}$ & $97.6 \mathrm{a}$ & $51.6 \mathrm{abc}$ & $40.1 \mathrm{ab}$ \\
\hline $\begin{array}{c}\text { T3 :Salicylic acid } \\
\text { 1000ppm }\end{array}$ & $1.6 \mathrm{de}$ & $3.3 c$ & $98.4 \mathrm{~cd}$ & $96.7 \mathrm{~cd}$ & $47.6 \mathrm{~cd}$ & $37.6 \mathrm{bc}$ \\
\hline $\begin{array}{c}\mathrm{T}_{4}: \text { : Citric acid } \\
250 \mathrm{ppm}\end{array}$ & $1.3 \mathrm{~g}$ & $3.1 \mathrm{~cd}$ & $98.7 \mathrm{~b}$ & $96.9 \mathrm{bc}$ & $47.8 \mathrm{~cd}$ & $41.2 \mathrm{ab}$ \\
\hline $\begin{array}{c}\mathrm{T}_{5}: \text { : Citric acid } \\
\text { 500ppm }\end{array}$ & $1.4 \mathrm{f}$ & $2.9 \mathrm{e}$ & $98.5 \mathrm{bc}$ & $97.1 \mathrm{~b}$ & $47.4 \mathrm{~d}$ & $38.0 \mathrm{bc}$ \\
\hline $\begin{array}{c}\mathrm{T}_{6}: \text { : Citric acid } \\
1000 \mathrm{ppm}\end{array}$ & $2.5 b$ & $3.9 \mathrm{~b}$ & $97.5 \mathrm{~g}$ & $96.2 \mathrm{e}$ & $45.1 \mathrm{~d}$ & $29.1 \mathrm{~d}$ \\
\hline $\begin{array}{c}\mathrm{T}_{7} \text { : Folic acid } \\
\text { 250ppm }\end{array}$ & $1.7 \mathrm{~cd}$ & $3.1 \mathrm{~cd}$ & 98.3 de & $96.8 \mathrm{c}$ & $51.9 \mathrm{ab}$ & $35.7 \mathrm{c}$ \\
\hline $\begin{array}{l}\mathrm{T}_{8} \text { :Folic acid } \\
\text { 500ppm }\end{array}$ & $2.0 \mathrm{~b}$ & 3.4 bc & $98.0 \mathrm{f}$ & $96.6 \mathrm{~d}$ & $46.7 \mathrm{~d}$ & $39.4 \mathrm{bc}$ \\
\hline $\begin{array}{l}\mathrm{T}_{9}: \text { Folic acid } \\
\text { 1000ppm }\end{array}$ & $1.5 \mathrm{e}$ & $3.2 \mathrm{~cd}$ & $98.5 \mathrm{bc}$ & $96.8 \mathrm{c}$ & $48.9 \mathrm{bcd}$ & $39.1 \mathrm{bc}$ \\
\hline $\mathrm{T}_{10}$ :Control & $4.1 \mathrm{a}$ & $6.6 \mathrm{a}$ & $95.9 \mathrm{~h}$ & $93.4 \mathrm{f}$ & $46.8 \mathrm{~d}$ & $38.5 \mathrm{bc}$ \\
\hline
\end{tabular}

Values having the same letter(s) in the same column in each season are not significant by Duncan's multiple range test, $5 \%$ level. 
Results concerning juice\%, in the two seasons the least significant values of juice $\%$ were obtained by $\mathrm{T}_{10}$ (control). By increasing salicylic acid levels gradually up to $1000 \mathrm{ppm}$, juice\% decreased so the highest values of juice\% were obtained by the first level of salicylic acid in both growing seasons. Data revealed that the highest significant values of juice\% were gained by the first level of citric acid in the two seasons. The first and the second levels of folic acid ( $T_{7}$ and $\left.T_{8}\right)$ gave the highest values of juice\% in first and second seasons, respectively. In general, salicylic acid at 250 ppm recorded highest juice\%.

The previous positive action of the investigated antioxidants on quality of Navel orange are in harmony with those obtained by Abo El-Komsan et al (2003) on "Balady" orange trees, Ahmed and Abdelaal, (2007) on "Anna" apple, Mansour et al (2008) on "Le- Conte" pear, Abada and Abd ElHameed, (2010) on "Flame seedless" grapevines, Mansour et al (2010) on four mango cultivars, Ibrahim et al (2013) on "Zaghloul" date palms, Mohamed, (2014) on "Thompson seedless" grapevines, and Merwad et al (2015) on "Zaghloul" date palm, they found that the spraying with antioxidant materials was very effective in improving fruit physical properties of several different plants.

The positive action of salicylic acid on fruiting and fruit quality parameters could be attributed to several processes such as enhancing cell division, the biosynthesis of sugar, plant pigments, cell protection from free radicals that responsible of plant senescence and the tolerance of plants to all stresses (Joseph et al 2010). The positive action of folic acid on stimulating growth and nutritional status of the plants led to improved fruit quality (Prusky, 1988).

Antioxidants can improve fruit size by increasing carbohydrates availability to fruit or by increasing fruit sink strength (Agusti et al 1995). As as well as, the improving fruit size could be explaining away by role both salicylic and citric acid as aauxinic action (Maksoud et al 2009) and role of folic acid as a central cofactor for one-carbon transfer reactions (Jabrin et al 2003).

Effect of spraying with some antioxidant materials on fruit chemical properties: Data presented in Table (8) show the effect of antioxidants spraying on T.S.S., total acidity, T.S.S./ acid ratio and vitamin $\mathrm{C}$. Data indicate that, all fruit chemical properties were significantly affected by spraying with three antioxidants by different levels in the two seasons. Control treatment $\left(T_{10}\right)$ gave the least significant values of T.S.S. followed by $T_{5}$, $T_{6}$ and $T_{8}$ with lack significant difference among them especially in the first season. In general, spraying with $250 \mathrm{ppm}$ citric acid gave the highest values of T.S.S.

In respect to total acidity, in the two seasons $T_{10}$ gave the highest values of total acidity, wearers the lower values were recorded by $\mathrm{T}_{2}$ (500 ppm salicylic acid) than other levels of salicylic acid. With respect to citric acid levels, the third level $\left(T_{6}\right)$ in first season and the first level $\left(T_{4}\right)$ in second season gave the lower values of total acidity than other levels of citric acid. Concerning to folic acid, the least values of total acidity were recorded by only $T_{7}$ in 2016 season but by $T_{9}$ and $T_{7}$ in 2017 season without any significant different between them. In general, the least values of total acidity were obtained by $\mathrm{T}_{6}$ (1000 ppm citric acid).

Regarding to T.S.S./ acid ratio, the data indicate that in the two growing seasons, the least significant values were obtained by $\mathrm{T}_{10}$ (untreated trees). In respect to salicylic acid levels, the highest significant values of T.S.S./ acid ratio were obtained by $\mathrm{T}_{2}$ (500 ppm salicylic acid) in the first season only. Whereas, the first level of citric acid $\left(T_{4}\right)$ gave the highest significant values of T.S.S./ acid ratio. Otherwise, the first level of folic acid $\left(T_{7}\right)$ gave the highest significant values of T.S.S./ acid ratio in the first season only. In general, the highest values of T.S.S./ acid ratio were obtained by $\mathrm{T}_{4}$ (250 ppm citric acid).

With respect to Vitamin C (ascorbic acid), during the two growing seasons the least significant values were obtained by control $\left(T_{10}\right)$. On the other hand, Vitamin $C$ was increased gradually by increasing salicylic acid level up to $1000 \mathrm{ppm}$. Regarding to citric acid levels, the second level of citric acid gave higher values of Vitamin $C$ than the other levels in the two seasons. The second level of folic acid recorded the higher values of Vitamin $C$ than other folic acid levels in the two seasons. Treatment $T_{3}(1000 \mathrm{ppm}$ salicylic acid) had the highest Vitamin $\mathrm{C}$ content.

It is clear that physical and chemical fruit properties of Navel orange trees were significantly increased in most cases by $\mathrm{T}_{2}$ (500 ppm salicylic acid) which gave the highest vales of all physical and chemical fruit properties. 
Table 8. Effect of spraying with some antioxidants on fruit chemical properties of Navel orange trees in 2016 and 2017 seasons

\begin{tabular}{|c|c|c|c|c|c|c|c|c|}
\hline \multirow[t]{2}{*}{ Treatments } & \begin{tabular}{|c|} 
Total \\
Soluble \\
Solids \\
\end{tabular} & \begin{tabular}{|c|} 
Total \\
acidity \\
$(\%)$
\end{tabular} & $\begin{array}{c}\begin{array}{c}\text { T.S.S./acid } \\
\text { ratio }\end{array} \\
\end{array}$ & \begin{tabular}{|c} 
Ascorbic acid \\
(mg/100 ml \\
juic)
\end{tabular} & \begin{tabular}{|c|} 
Total \\
soluble \\
Solids \\
\end{tabular} & \begin{tabular}{|c|} 
Total \\
acidity \\
$(\%)$
\end{tabular} & $\begin{array}{c}\text { T.S.S./acid } \\
\text { Ratio }\end{array}$ & $\begin{array}{c}\text { Ascorbic acid } \\
(\mathrm{mg} / 100 \mathrm{ml} \\
\text { juice })\end{array}$ \\
\hline & \multicolumn{4}{|c|}{ Season 2016} & \multicolumn{4}{|c|}{ Season 2017} \\
\hline $\begin{array}{c}\mathrm{T}_{1}: \text { Salicylic acid } \\
\text { 250ppm }\end{array}$ & $12.5 \mathrm{abc}$ & $0.67 a$ & $18.7 \mathrm{~d}$ & $31.8 d$ & $12.1 \mathrm{a}$ & $0.57 \mathrm{bc}$ & $21.1 \mathrm{~b}$ & $30.0 \mathrm{bcd}$ \\
\hline $\begin{array}{c}\mathrm{T}_{2}: \text { Salicylic acid } \\
\text { 500ppm }\end{array}$ & $12.2 \mathrm{a}-\mathrm{d}$ & $0.54 \mathrm{~cd}$ & $22.6 \mathrm{a}$ & $33.8 \mathrm{~cd}$ & $12.2 \mathrm{a}$ & $0.54 \mathrm{~cd}$ & $22.7 \mathrm{~b}$ & $34.0 \mathrm{~b}$ \\
\hline $\begin{array}{c}\text { T3 :Salicylic acid } \\
\text { 1000ppm }\end{array}$ & $12.7 \mathrm{a}$ & $0.62 a$ & $20.6 b c$ & $44.0 \mathrm{a}$ & $12.3 \mathrm{a}$ & $0.55 \mathrm{bcd}$ & $22.2 \mathrm{~b}$ & $40.3 a$ \\
\hline $\begin{array}{c}\mathrm{T}_{4} \text { : Citric acid } \\
\text { 250ppm }\end{array}$ & $12.8 \mathrm{a}$ & $0.55 c$ & $23.3 \mathrm{a}$ & $31.8 \mathrm{~d}$ & $13.0 \mathrm{a}$ & $0.49 \mathrm{e}$ & $26.7 \mathrm{a}$ & $24.8 d$ \\
\hline $\begin{array}{c}\mathrm{T}_{5}: \text { Citric acid } \\
500 p p m\end{array}$ & $11.9 \mathrm{~cd}$ & $0.62 a$ & $19.2 \mathrm{~cd}$ & $43.3 \mathrm{a}$ & $12.3 \mathrm{a}$ & $0.56 b c$ & $22.0 \mathrm{~b}$ & $34.7 \mathrm{~b}$ \\
\hline $\begin{array}{c}T_{6}: \text { Citric acid } \\
\text { 1000ppm }\end{array}$ & $11.8 \mathrm{~d}$ & $0.54 \mathrm{~cd}$ & $21.9 a b$ & $39.9 \mathrm{~b}$ & $12.1 \mathrm{a}$ & $0.52 d$ & $23.4 \mathrm{~b}$ & $33.7 \mathrm{~b}$ \\
\hline $\begin{array}{c}\mathrm{T}_{7} \text { :Folic acid } \\
\text { 250ppm }\end{array}$ & $12.6 a b$ & $0.55 c$ & $22.9 \mathrm{a}$ & $35.8 \mathrm{c}$ & $12.8 \mathrm{a}$ & $0.55 \mathrm{bcd}$ & $23.6 \mathrm{~b}$ & $31.4 \mathrm{bc}$ \\
\hline $\begin{array}{c}\mathrm{T}_{8} \text { :Folic acid } \\
500 p p m\end{array}$ & $11.9 \mathrm{~cd}$ & $0.64 a$ & $18.6 \mathrm{~d}$ & $43.3 \mathrm{a}$ & $12.5 \mathrm{a}$ & $0.58 a b$ & $21.5 b$ & $35.6 a b$ \\
\hline $\begin{array}{c}T_{9}: \text { Folic acid } \\
\text { 1000ppm }\end{array}$ & $12.1 \mathrm{a}-\mathrm{d}$ & $0.58 b$ & $20.7 b c$ & $34.0 \mathrm{~cd}$ & $12.3 \mathrm{a}$ & $0.54 \mathrm{~cd}$ & $22.8 \mathrm{~b}$ & $26.0 \mathrm{~cd}$ \\
\hline $\mathrm{T}_{10}$ :Control & $10.8 \mathrm{e}$ & $0.71 a$ & $15.2 \mathrm{e}$ & $15.5 \mathrm{e}$ & $10.8 b$ & $0.62 \mathrm{a}$ & $17.3 \mathrm{c}$ & $14.8 \mathrm{e}$ \\
\hline
\end{tabular}

Values having the same letter(s) in the same column in each season are not significant by Duncan's multiple range test, $5 \%$ level.

The recorded results of citric acid on enhancing Navel orange fruit quality are in harmony with earlier studies of Ali, (2000) on "Flame seedless" grapevines, Ahmed et al (2002) on "Flame seedless" grapevines and Fayed, (2010) on "Thompson seedless" grapevine, they concluded that the spraying with antioxidant materials was very effective in improving fruit quality such as reducing total acidity, raising T.S.S. and vitamin C.

These data could explain by, citric acid have several influences on trees such as increasing photosynthetic pigment which reflected on photosynthesis process and therefore increase in total soluble solids Fayed (2010).

Effect of spraying with some antioxidant materials on some chemical analysis of leaves: Data presented in Table (9) show the effect of antioxidants spraying on total protein and total phenolic compounds. Data indicate that, in the two seasons. The least significant values were recorded by $\mathrm{T}_{1}$ (250 ppm salicylic acid), $\mathrm{T}_{2}$ (500 ppm salicylic acid) and $T_{10}$ (control). Three citric acid levels $T_{4}, T_{5}$ and $T_{6}$ gave more or less similar values with lack significant difference among them in the two seasons. On the other hand, total protein increased gradually by increasing folic acid levels up to $500 \mathrm{ppm}$ while more increasing in folic acid level 1000 ppm decreased total protein significantly in the two growing seasons. Therefore, the second level of folic acid 500 ppm gave the highest percentage of total protein content.

The results could be explaining by, folic acid has fundamental biochemical action in nucleic acid synthesis and amino acid metabolism Andrew et al (2000). Folic acid improves plants to produce RNA, a nuclic acid that carries information from DNA to plant cell structures known as ribosomes and helps plant synthesize protein Shadia (2017). The positive action of folic acid is stimulating several cellular reactions which improved growth characters such as metabolism of amino acids and transport of amino acid to the appropriate location in protein chain creation (Kelly, 1998), synthesis of 
methionine, the formation of lignin, chlorophyll and choline led to improvement in yield Abo-Hinna and Merza (2012).

Total phenolic compounds was significantly affected by spraying different levels of antioxidants during the two growing seasons. Untreated trees $\left(T_{10}\right)$ gave the least values of total phenolic compounds in the two seasons. The third level of salicylic acid and the second level of citric acid gave higher significant values of total phenolic compounds than other salicylic and citric acid levels in the two seasons. Otherwise, it is observed that increasing in folic acid level led to increasing in total phenolic compounds up to $1000 \mathrm{ppm}$ in both growing seasons. Therefore, $T_{9} " 1000 \mathrm{ppm}$ folic acid" gave the highest values of total phenolic compounds.

Folic acid stimulate phenolic structural development and makes available free phenolic to scavenging free-radical, therefore the phenolic stimulation due to enhancement in growth parameters Elizabeth et al (2007).

Effect of spraying with some antioxidants on leaf macronutrients content: Data presented in Table (10) show the effect of antioxidants spraying on $\mathrm{N}, \mathrm{P}, \mathrm{K}, \mathrm{Ca}$ and $\mathrm{Mg}$ content of leaves. Data indicate that, leaf macronutrients content were significantly affected by spraying different levels of antioxidants in both growing seasons. The least significant values of leaf $\mathrm{N}$ content were obtained by $T_{1}$ and $T_{2}$ in 2016 and 2017 seasons, respectively followed closely by $T_{9}$ and $T_{10}$ in the two growing seasons. The highest significant values of nitrogen content recorded by $\mathrm{T}_{8}(500 \mathrm{ppm}$ folic acid) during the two seasons followed by lack difference with $T_{3}, T_{5}, T_{6}$ and $T_{7}$ especially in the first season. So, spraying with 500 ppm folic acid could be considered the superior treatment for nitrogen content in Navel orange leaves.

Regarding to phosphorus content, $\mathrm{T}_{10}$ gave the least significant values of $P$ content during the two growing seasons. On the other hand, $\mathrm{T}_{4}(250 \mathrm{ppm}$ citric acid) gave the highest $P$ content during the two seasons followed with $T_{1}, T_{2}, T_{3}, T_{5}$ and $T_{9}$ in the second season only.

Regarding to potassium content, the least significant values were obtained by $T_{10}$ (control treatment) in the two growing seasons. In respect to the three antioxidant treatments it could be arranged in ascending order as salicylic acid treatments followed by citric acid and folic acid treatments. Therefore, the highest significant values of $\mathrm{K}$ con- tent were recorded by spraying with 250 in both seasons and 500 ppm folic acid in the first season. Regarding to $\mathrm{Ca}$ content, the spraying with the second and third level of citric acid in 2016 season, the first level of salicylic acid in 2017 season and all levels of folic acid in the two seasons could be considered the superior treatments for $\mathrm{Ca}$ content in Navel orange leaves.

Regarding to $\mathrm{Mg}$ content, the least significant values were obtained by $T_{10}$ (control treatment) in the two seasons. The highest significant values of Mg content were recorded by the second level of salicylic acid, the first and second levels of citric acid and the third level of folic acid especially in the second season.

It seems that macronutrients content of Navel orange trees were significantly increased by folic acid treatments compared with salicylic and citric acid treatments especially spraying with 250 and 500 ppm folic acid.

Effect of spraying with some antioxidant materials on leaf micronutrients content: Data presented in Table (10) show the effect of antioxidants spraying on $\mathrm{Fe}, \mathrm{Zn}$ and $\mathrm{Mn}$ content of leaves. Data indicate that, leaf micronutrients content were significantly affected by spraying different levels of antioxidants in both growing. The least significant values of leaf $\mathrm{Fe}$ content were obtained by $T_{7}$ in the two growing seasons. On the other hand, the highest significant values of $\mathrm{Fe}$ content recorded by T3 (1000 ppm salicylic acid) and $T_{10}$ (untreated trees) during the two season. With respect to $\mathrm{Zn}$ content, the spraying with 1000 ppm salicylic acid $\left(T_{3}\right)$ gave the highest significant values of $\mathrm{Zn}$ content of Navel oranges leaves. Other different levels of antioxidants gave more or less similar values from the same statistical stand point.

Regarding to Mn content, the least significant values were obtained by, $T_{4}, T_{5}$ and $T_{10}$ in the two growing seasons in addition to $T_{1}$ in 2016 season and $T_{7}$ in 2017 season. In respect to the three antioxidant treatments it could be arranged in descending order as salicylic acid treatments followed by folic acid and citric acid treatments. Therefore, the highest significant values of $\mathrm{Mn}$ content were recorded by spraying with 1000 ppm salicylic acid in the two seasons.

It seems that micronutrients content of Navel orange trees were significantly increased by the spraying trees with the third level of salicylic acid and the first level of folic acid. 

Nutritional Status of 'Navel Orange' Trees

Table 9. Effect of spraying with some antioxidants on total protein and total phenolic compounds of Navel orange trees in 2016 and 2017 seasons

\begin{tabular}{|c|c|c|c|c|}
\hline \multirow[t]{2}{*}{ Treatments } & $\begin{array}{l}\text { Total } \\
\text { Protein } \\
(\%)\end{array}$ & $\begin{array}{c}\text { Total phenolic } \\
\text { compounds } \\
\text { ( } \mu \mathrm{g} / \mathrm{g} \text { D.W.) }\end{array}$ & $\begin{array}{l}\text { Total } \\
\text { Protein } \\
(\%)\end{array}$ & $\begin{array}{c}\text { Total phenolic } \\
\text { compounds } \\
\text { ( } \mu \mathrm{g} / \mathrm{g} \text { D.W.) }\end{array}$ \\
\hline & \multicolumn{2}{|c|}{ Season 2016} & \multicolumn{2}{|c|}{ Season 2017} \\
\hline $\begin{array}{c}\mathrm{T}_{1} \text { :Salicylic acid } \\
\text { 250ppm }\end{array}$ & $15.0 \mathrm{~b}$ & $541.5 \mathrm{e}$ & 18.0 cde & 583.8 e \\
\hline $\begin{array}{c}\mathrm{T}_{2}: \text { Salicylic acid } \\
\text { 500ppm }\end{array}$ & $16.1 \mathrm{~b}$ & $475.8 \mathrm{e}$ & $16.8 \mathrm{e}$ & $551.0 \mathrm{e}$ \\
\hline $\begin{array}{c}\text { T3 }: \text { Salicylic acid } \\
\text { 1000ppm }\end{array}$ & $20.0 \mathrm{a}$ & $1012.3 b$ & $19.8 b c$ & $1125.8 \mathrm{~b}$ \\
\hline $\begin{array}{c}\mathrm{T}_{4}: \text { :Citric acid } \\
250 \mathrm{ppm}\end{array}$ & $17.3 \mathrm{ab}$ & $665.3 d$ & $17.3 \mathrm{de}$ & 704.0 de \\
\hline $\begin{array}{c}\mathrm{T}_{5}: \text { :Citric acid } \\
500 \mathrm{ppm}\end{array}$ & $17.5 \mathrm{ab}$ & $934.3 \mathrm{~b}$ & 18.4cde & $969.0 \mathrm{bc}$ \\
\hline $\begin{array}{c}\mathrm{T}_{6}: \text { Citric acid } \\
\text { 1000ppm }\end{array}$ & $17.9 a b$ & $551.8 \mathrm{e}$ & $20.6 \mathrm{~b}$ & $559.4 \mathrm{e}$ \\
\hline $\begin{array}{c}\mathrm{T}_{7} \text { :Folic acid } \\
\text { 250ppm }\end{array}$ & $18.2 \mathrm{ab}$ & $734.8 \mathrm{~cd}$ & $19.4 \mathrm{bcd}$ & $802.5 \mathrm{~cd}$ \\
\hline $\begin{array}{c}\mathrm{T}_{8} \text { :Folic acid } \\
500 \mathrm{ppm}\end{array}$ & $20.5 \mathrm{a}$ & $789.8 \mathrm{c}$ & $22.6 \mathrm{a}$ & $880.5 \mathrm{~cd}$ \\
\hline $\begin{array}{c}T_{9}: \text { Folic acid } \\
\text { 1000ppm }\end{array}$ & $15.4 \mathrm{~b}$ & $1315.3 \mathrm{a}$ & $17.6 \mathrm{cde}$ & $1413.0 \mathrm{a}$ \\
\hline $\mathrm{T}_{10}:$ Control & $16.6 \mathrm{~b}$ & $352.3 \mathrm{f}$ & 18.2 cde & $355.5 \mathrm{f}$ \\
\hline
\end{tabular}

Values having the same letter(s) in the same column in each season are not significant by Duncan's multiple range test, $5 \%$ level

Table 10. Effect of spraying with some antioxidants on leaf macronutrients content of Navel orange trees in 2016 and 2017 seasons.

\begin{tabular}{|c|c|c|c|c|c|c|c|c|c|c|}
\hline & $\begin{array}{l}\mathbf{N} \\
(\%)\end{array}$ & $\begin{array}{l}P \\
(\%)\end{array}$ & $\begin{array}{c}\mathrm{K} \\
(\%)\end{array}$ & $\begin{array}{l}\mathrm{Ca} \\
(\%)\end{array}$ & $\begin{array}{l}\mathrm{Mg} \\
(\%)\end{array}$ & $\begin{array}{l}N \\
(\%)\end{array}$ & $\begin{array}{l}\mathbf{P} \\
(\%)\end{array}$ & $\begin{array}{c}K \\
(\%)\end{array}$ & $\begin{array}{l}\mathbf{C a} \\
(\%)\end{array}$ & $\begin{array}{l}\mathrm{Mg} \\
(\%)\end{array}$ \\
\hline Treatments & \multicolumn{5}{|c|}{ Season 2016} & \multicolumn{5}{|c|}{ Season 2017} \\
\hline $\begin{array}{c}\mathrm{T}_{1} \text { :Salicylic acid } \\
\text { 250ppm }\end{array}$ & $2.4 \mathrm{c}$ & $0.16 \mathrm{bc}$ & $0.39 d$ & $2.5 \mathrm{bcd}$ & $0.60 d$ & $2.9 \mathrm{cde}$ & $0.15 \mathrm{a}-\mathrm{d}$ & $0.41 \mathrm{~g}$ & $3.5 b$ & $0.61 \mathrm{c}$ \\
\hline $\begin{array}{c}\mathrm{T}_{2}: \text { Salicylic acid } \\
500 \mathrm{ppm}\end{array}$ & $2.6 \mathrm{c}$ & $0.15 \mathrm{~cd}$ & $0.43 d$ & $2.4 \mathrm{bcd}$ & $0.60 \mathrm{~d}$ & $2.7 \mathrm{e}$ & $0.17 \mathrm{a}$ & $0.44 \mathrm{fg}$ & $3.1 d$ & $0.67 \mathrm{a}$ \\
\hline $\begin{array}{c}\text { T3 }: \text { Salicylic acid } \\
\text { 1000ppm }\end{array}$ & $3.2 \mathrm{ab}$ & $0.17 \mathrm{~b}$ & $0.44 d$ & $2.0 d$ & $0.56 \mathrm{e}$ & $3.2 b c$ & $0.17 a b$ & $0.44 \mathrm{fg}$ & $3.2 d$ & $0.56 \mathrm{~d}$ \\
\hline $\begin{array}{c}\mathrm{T}_{4}: \text { :Citric acid } \\
\text { 250ppm }\end{array}$ & $2.8 \mathrm{bc}$ & $0.20 \mathrm{a}$ & $0.52 \mathrm{bc}$ & $2.5 \mathrm{bcd}$ & $0.68 \mathrm{a}$ & $2.8 \mathrm{de}$ & $0.17 \mathrm{a}$ & $0.52 \mathrm{~cd}$ & $3.1 \mathrm{~d}$ & $0.68 a$ \\
\hline $\begin{array}{l}\mathrm{T}_{5}: \text { Citric acid } \\
500 \mathrm{ppm}\end{array}$ & $2.8 \mathrm{abc}$ & $0.16 \mathrm{bc}$ & $0.53 \mathrm{bc}$ & 3.3abc & $0.65 b c$ & $3.0 \mathrm{cde}$ & $0.16 a b c$ & $0.53 \mathrm{c}$ & $3.0 \mathrm{~d}$ & $0.67 \mathrm{a}$ \\
\hline $\begin{array}{c}\mathrm{T}_{6}: \text { Citric acid } \\
1000 \mathrm{ppm}\end{array}$ & 2.9abc & $0.15 \mathrm{~cd}$ & $0.54 \mathrm{~b}$ & $3.5 a b$ & $0.62 \mathrm{~cd}$ & $3.3 \mathrm{~b}$ & $0.14 \mathrm{~d}$ & $0.48 \mathrm{de}$ & $3.1 \mathrm{~d}$ & $0.52 \mathrm{e}$ \\
\hline $\begin{array}{c}\mathrm{T}_{7} \text { :Folic acid } \\
\text { 250ppm }\end{array}$ & 2.9abc & $0.15 \mathrm{~cd}$ & $0.72 \mathrm{a}$ & $3.5 a b$ & $0.65 a b$ & $3.1 \mathrm{bcd}$ & $0.15 \mathrm{bcd}$ & $0.72 \mathrm{a}$ & $3.0 \mathrm{~d}$ & $0.55 d$ \\
\hline $\begin{array}{l}\mathrm{T}_{8} \text { :Folic acid } \\
500 p p m\end{array}$ & $3.3 \mathrm{a}$ & $0.14 \mathrm{de}$ & $0.67 \mathrm{a}$ & $3.7 a$ & $0.66 \mathrm{ab}$ & $3.6 \mathrm{a}$ & $0.15 \mathrm{~cd}$ & $0.68 \mathrm{~b}$ & $3.3 \mathrm{c}$ & $0.63 \mathrm{~b}$ \\
\hline $\begin{array}{l}\mathrm{T}_{9} \text { :Folic acid } \\
\text { 1000ppm }\end{array}$ & $2.5 \mathrm{c}$ & $0.15 \mathrm{~cd}$ & $0.46 \mathrm{~cd}$ & $3.9 a$ & $0.66 \mathrm{ab}$ & $2.8 \mathrm{cde}$ & $0.16 \mathrm{a}-\mathrm{d}$ & $0.46 \mathrm{ef}$ & $3.9 a$ & $0.67 \mathrm{a}$ \\
\hline $\mathrm{T}_{10}$ : Control & $2.7 \mathrm{c}$ & $0.13 \mathrm{f}$ & $0.28 \mathrm{e}$ & $2.2 \mathrm{~cd}$ & $0.48 \mathrm{f}$ & 2.9cde & $0.12 \mathrm{e}$ & $0.25 \mathrm{~h}$ & $2.5 \mathrm{e}$ & $0.52 \mathrm{e}$ \\
\hline
\end{tabular}

Values having the same letter(s) in the same column in each season are not significant by Duncan's multiple range test, $5 \%$ level.

$\begin{array}{cccccc} & \% \mathrm{~N} & \% \mathrm{P} & \% \mathrm{~K} & \mathrm{Ca} \% & \% \mathrm{Mg} \\ \text { Optimum } & 2.5-2.7 & 0.12-0.16 & 1.2-1.7 & 3-4.9 & 0.30-0.49\end{array}$


Table 11. Effect of spraying with some antioxidants on leaf micronutrients content of Navel orange trees in 2016 and 2017 seasons

\begin{tabular}{|c|c|c|c|c|c|c|}
\hline \multirow{2}{*}{ Treatments } & $\begin{array}{c}\mathrm{Fe} \\
(\mathrm{ppm})\end{array}$ & $\begin{array}{c}\mathrm{Zn} \\
(\mathrm{ppm})\end{array}$ & $\begin{array}{c}\text { Mn } \\
(p p m)\end{array}$ & $\begin{array}{c}\mathrm{Fe} \\
(\mathrm{ppm})\end{array}$ & $\begin{array}{c}\mathrm{Zn} \\
(\mathrm{ppm})\end{array}$ & $\begin{array}{c}\text { Mn } \\
(\mathrm{ppm})\end{array}$ \\
\hline & \multicolumn{3}{|c|}{ Season 2016} & \multicolumn{3}{|c|}{ Season 2017} \\
\hline $\begin{array}{c}\mathrm{T}_{1}: \text { Salicylic acid } \\
\text { 250ppm }\end{array}$ & $178.6 \mathrm{~cd}$ & $20.3 b$ & $21.8 \mathrm{a}$ & $282.4 \mathrm{~b}$ & $23.1 \mathrm{~b}$ & $21.0 \mathrm{~d}$ \\
\hline $\begin{array}{c}\mathrm{T}_{2}: \text { Salicylic acid } \\
\text { 500ppm }\end{array}$ & $189.6 \mathrm{~cd}$ & 13.3ef & $15.8 c$ & $179.5 \mathrm{~d}$ & $18.5 \mathrm{c}$ & $22.8 \mathrm{bc}$ \\
\hline $\begin{array}{c}\text { T3 :Salicylic acid } \\
\text { 1000ppm }\end{array}$ & $338.1 \mathrm{a}$ & $24.3 \mathrm{a}$ & $20.3 \mathrm{a}$ & $386.3 \mathrm{a}$ & $29.4 \mathrm{a}$ & $25.3 \mathrm{a}$ \\
\hline $\begin{array}{c}\mathrm{T}_{4}: \text { Citric acid } \\
\text { 250ppm }\end{array}$ & $198.0 \mathrm{~cd}$ & $16.8 \mathrm{~cd}$ & $14.3 \mathrm{~cd}$ & $235.9 c$ & $19.1 \mathrm{c}$ & $22.3 \mathrm{bcd}$ \\
\hline $\begin{array}{c}\mathrm{T}_{5}: \text { Citric acid } \\
\text { 500ppm }\end{array}$ & $271.0 \mathrm{~b}$ & $11.3 f g$ & $12.3 d$ & $266.9 b c$ & $24.1 \mathrm{~b}$ & $21.3 \mathrm{~cd}$ \\
\hline $\begin{array}{c}\mathrm{T}_{6}: \text { Citric acid } \\
\text { 1000ppm }\end{array}$ & $240.1 b c$ & $15.8 \mathrm{de}$ & $16.0 \mathrm{bc}$ & 260.9 bc & $22.6 \mathrm{~b}$ & $26.0 \mathrm{a}$ \\
\hline $\begin{array}{c}\mathrm{T}_{7}: \text { Folic acid } \\
\text { 250ppm }\end{array}$ & $172.1 \mathrm{~d}$ & $15.0 \mathrm{de}$ & $12.0 \mathrm{~d}$ & 139.4 e & $24.5 \mathrm{~b}$ & $23.0 \mathrm{bc}$ \\
\hline $\begin{array}{c}\mathrm{T}_{8}: \text { Folic acid } \\
500 \mathrm{ppm}\end{array}$ & $195.7 \mathrm{~cd}$ & $16.8 \mathrm{~cd}$ & $18.0 \mathrm{~b}$ & $168.4 \mathrm{de}$ & $23.8 \mathrm{~b}$ & $25.1 \mathrm{a}$ \\
\hline $\begin{array}{c}T_{9}: \text { Folic acid } \\
\text { 1000ppm }\end{array}$ & $265.6 \mathrm{~b}$ & $9.0 \mathrm{~g}$ & $22.0 \mathrm{a}$ & $245.0 \mathrm{bc}$ & $10.0 \mathrm{~d}$ & $23.6 \mathrm{~b}$ \\
\hline $\mathrm{T}_{10}$ :Control & $348.5 \mathrm{a}$ & $19.0 \mathrm{bc}$ & $13.0 \mathrm{~d}$ & $418.0 \mathrm{a}$ & $23.4 \mathrm{~b}$ & $22.0 \mathrm{bcd}$ \\
\hline
\end{tabular}

Values having the same letter(s) in the same column in each season are not significant by Duncan's multiple range test, $5 \%$ level.

$\begin{array}{lccc} & \begin{array}{c}\text { Fe } \\ (\mathrm{ppm})\end{array} & \begin{array}{c}\mathrm{Zn} \\ (\mathrm{ppm})\end{array} & \begin{array}{c}\text { Mn } \\ (\mathrm{ppm})\end{array} \\ \begin{array}{l}\text { Optimum } \\ \text { Obreza et al (1992) }\end{array} & 60-120 & 25-100 & 25-100\end{array}$

These results are in agreement with those founded by Mousa et al (1994), Abdel-Messih and Eid (1999), Mohamed (2004) on wheat plant. The positive action of folic acid is stimulating $\mathrm{N}, \mathrm{P}$, $\mathrm{K}, \mathrm{Ca}, \mathrm{Mg}, \mathrm{Zn}, \mathrm{Fe}$ and $\mathrm{Mn}$ in the leaves of trees Naheif (2013). Salicylic acid stimulating ion uptake and transport Kassem et al (2011). Citric acid has an effect on many metabolic physiological processes increased such as leaf content of $N, P, K$ Maksoud et al (2009), Mg, $\mathrm{Zn}$ and Fe Hamdy et al (2007) and improving the availability of $\mathrm{Fe}$ Legaz et al (1992), Mengel et al (1994) and Miller et al (1994).

\section{CONCLUSION}

From the foregoing results, it could be concluded that antioxidant materials were affected significantly on Navel orange growth, yield, fruit quality and nutritional status. In most cases, the second level of salicylic acid (500 ppm) gave the highest significant values of total chlorophyll content, fruit set\%, fruit weight, fruit number per tree, yield, pulp: fruit\%, juice\%, juice weight and $\mathrm{Mg}$ content of leaves and at the same time gave the least values of peel: fruit\% and fruit drop\%. Regarding to citric acid levels in most cases, the second level (500 ppm citric acid) gave the highest significant values of leaf area, fruit set\%, fruit number per tree, yield, fruit weight, fruit volume, juice weight and juice volume and at the same time gave the least values of fruit drop\%. Regarding to folic acid levels in most cases, the first level (250 ppm folic acid) gave the highest significant values of fruit weight, yield, fruit volume, juice volume, juice weight and leaf content of $\mathrm{K}$ and $\mathrm{Fe}$ and at the same time gave the least values of fruit drop\%. Therefore, the best treatments for enhancing Navel orange growth, yield, fruit quality and nutritional status were using treatments 500 ppm salicylic acid, 500 ppm citric 
acid or $250 \mathrm{ppm}$ folic acid. Treatment 500 ppm salicylic acid was the best from economical point of view and may be recommended as good treatment for enhancing Navel orange growth, yield, fruit quality and nutritional status especially under old citrus orchard.

\section{REFERENCES}

Abada M.A. 2014. A comparative study for the effect of green tea extract and some antioxidants on Thompson seedless grapevines. Int. J. of Plant \& Soil Sci. 3(10), 1333-1342.

Abada M.A.M. and Abd El-Hameed H.M. 2010. The beneficial effects of spraying salicylic and citric acids on Flame seedless grapevines. The Sixth Inter. Sustain Agric and Develop. Fac. of Agric., Fayoum Univ., Fayoum, Egypt, pp. 153-164.

Abdel Aal A.M.K. and Oraby-Mona M.M. 2013. Using salicylic acid for alleviating the adverse effects of water salinity on growth and nutritional status of mango cv. Alphonse seedlings. World Rural Observations 5(2), 41-46.

Abdel-Messih S. and Eid M. 1999. Response of wheat crop to different levels of nitrogen fertilizer and foliar spray with ascorbic acid. Egypt J. Appl. Sci., Zagazig Univ., Zagazig, Egypt, 14(2), 132-142.

Abdou M., Abdalla M., Hegazy A. and Marzok Z.S. 2011. Physiological studies on clove basil plant. J. Plant Production, Mansoura Univ., Mansoura, Egypt, 2(11), 1451-1469.

Abo El-Komsan E.E., Hegab M.Y. and Fouad A.A. 2003. Response of Balady orange trees to application of some nutrients and citric. Egypt $\mathbf{J}$. Appl. Sci., 18(3), 228-246.

Abo-Hinna M.A. and Merza T.K. 2012. Effect of organic manure, tuber weight and ascorbic acid spraying on some vegetative parameters and marketable yield of potato (Solanum tuberosum L.) grown in sandy soil. Agric. Sci. Kufa Magazine: 4, 15-29.

Agusti M., El-Otmani M., Juan M. and Almela V. 1995. Effect of 3,5,6 trichloro-2-pyridyloy acetic acid on Clementine early fruitlet development and fruit size at maturity. J. Hort. Sci., 70, 955996.

Ahmed F.F., Mansour A.E.M., Mohamed A.Y., Mostafa E.A.M. and Ashour N.E. 2013. Using silicon and salicylic acid for promoting production of Hindy Bisinnara mango trees grown under sandy soil. Middle East J. of Agric. Res., 2, 51-55.
Ahmed F.F., Mohamed Y. and Abdalla B.M. 2007. The relation between using some antioxidants and productivity of Sewy date palms. Minia J. Agric. Res. and Develop., 27(4), 753-770.

Ahmed F.F., Darwish O.H., Gobara A.A. and Ali A.H. 2002. Physiological studies on the effect of ascorbic and citric acid in combined with some micronutrients on Flame seedless grapevines. Minia J. of Agric. Res. \& Develop, 22(1), 105114.

Ahmed, F. and Abdelaal, A. 2007. Influence of spraying seaweed extract and citric acid on yield and fruit quality of Anna apple trees. In The $1^{\text {st }}$ Inter. Conf. on Desert cultivation, Minia Univ. Minia, Egypt, pp. 27-29.

Ali A.H. 2000. Response of Flame seedless grapevines to spraying with ascorbic acid and boron. Minia J. of Agric. Res. \& Develop, 20(1), 159-174.

Aly M., Harhash M., Rehab M. and El-Kelawy H. 2015. Effect of foliar application with calcium, potassium and zinc treatments on yield and fruit quality of Washington navel orange trees. Middle East J. Agric. Res., 4(3), 564-568.

Andrew W.J., Youngkoo C., Chen X. and Pandalai S.G. 2000. Vicissitudes of a vitamin. Recent Research Develop. in Photochemistry, 4, 8998.

A.O.A.C. 1990. Official Method of Analysis. 15th ed., Association of Official Analytical Chemists, TNC. Suite 400, 220 Wilson Boulevard. Arlington, Virginia. 22201 USA.

Chapman H.D. and Pratt P.E. 1961. Methods of Analysis for Soil, Plant and Water. Davis Agric. Sci. Pull Office Calif. Univ., pp. 220308.

Duncan D.B. 1955. Multiple Range and Multiple F Tests. Biometrics, 11, 1-42.

El-Badawy H.E.M. 2013. Effect of some antioxidants and micronutrients on growth, leaf mineral content, yield and fruit quality of Canino apricot trees. J. Appl. Sci. Res., 9(2), 1228-1237.

Elizabeth B., McCue P., Kwon Y. and Shetty K. 2007. Effect of vitamin $C$ and folic acid on seed vigour response and phenolic-linked antioxidant activity. Bioresource Technology 98, 13931404.

El-Sayed M., Ahmed M. and Ali A. 2000. Response of Flame seedless grapevine to application of ascorbic acid. In The $2^{\text {nd }}$ Conf. Sci. Assuit, Egypt, pp. 317-340.

El-Shazly S.M., Eisa A.M., Moảtamed A.M.H. and Kotb H.R.M. 2013. Effect of Some AgroChemicals Preharvest Foliar Application on 
Yield and Fruit Quality of "Swelling" Peach Trees. Alex. J. Agric. Res., 58(3), 219-229.

Emam M.M., El-Sweify A.H. and Helal N.M. 2011. Efficiencies of some vitamins in improving yield and quality of flax plant. African J. of Agric. Res., 6, 4362-4369.

Fayed T.A. 2010. Effect of some antioxidants on growth, yield and bunch characteristics of Thompson seedless grapevine. American Eurasian J. Agric. \& Environ Sci., 8(3), 322-328.

Hamdy I.M., Ahmed Y.M.I. and Ahmed F.F. 2007. Relation of Fruiting in Hindy Bisinara Mangoes to Foliar Nutrition with $\mathrm{Mg}, \mathrm{B}$ and $\mathrm{Zn}$ and some Antioxidants. African Crop Sci. Conference Proceedings, 8, 411-415.

http://www.upehc.org/Exports Orange.aspx.

Ibrahim H.I.M., Ahmed F.F., Akl A.M.A. and Rizk M.N.S. 2013. Improving Yield Quantitively and Qualitatively of Zaghloul Date Palms by Using some Antioxidants. Stem Cell, 4(2), 34-40.

Ibrahim M., El-Gawad H.A. and Bondok A. 2015. Physiological impacts of potassium citrate and folic acid on growth, yield and some viral diseases of potato plants. Middle East J. of Agric. Res., 4(3), 577-589.

Jabrin S., Ravanel S., Gambonnet B., Douce R. and Re beille F. 2003. One-carbon metabolism in plants. Regulation of tetrahydrofolate synthesis during germination and seedling development. Plant Physiol. 131, 1431-1439.

Jackson M.L. 1958. Soil Chemical Analysis, Englewood Cliffs, N.J.: Prentice-Hall, Inc. N.J., U.S.A. pp. 216-222.

Jones W.W. and Embleton T.W. 1969. Development and current status of citrus leaf analysis as guide to fertilization in California. Proceeding $1^{\text {st }}$ International Citrus Symposium, 3, 16691771.

Joseph B., Jini D. and Sujatha S. 2010. Insight into the role of exogenous salicylic acid on plants grown under salt environment, Asian J. Crop Sci., 2, 226-235.

Kassem H.A., Al-Obeed R.S., Ahmed M.A. and Omar A.K.H. 2011. Productivity, Fruit Quality and Profitability of Jujube Trees Improvement by Preharvest Application of Agro-Chemicals. Middle-East J. of Scientific Research 9(5), 628-637.

Kelly G.S. 1998. Folates: supplemental forms and the rapeutic application. Alternative Medicine Review 3, 208-220.

Kumar K.K., Vidyasaar R. and RAO K. 1988. Studies on growth and activity of photosynthetic enzymes on Sorghum bicolor $L$ as influenced by micronutrients. Procendian Natl, Sci. Acard Part B Biol. Sci., 54, 75-80.

Legaz F., Serna M.D., Primo-Millo E. and Martin B. 1992. Leaf Spray and Soil application of FeChelates to Navelina Orange Trees. Proc. Int. Soc. Citriculture 2, 613-617.

Lindsay W.L. and Norvell W.A. 1978. Development of DTPA micronutrient soil tests for zinc, iron, manganese and copper. Soil Sci. Soc. Am. J. 42, 421-428.

Maksoud M.A.S., Malaka A., El-Shamma M.S. and Fouad A.A. 2009. The beneficial effect of biofertilizer sand antioxidants on olive trees under calcareous soil conditions. World J. of Agric. Sci., 5(3), 350-352.

Mansour A.E.M., Ahmed F.F., Abdelaal A.M.K., Cimpoies G.P. and Shaaban E.A. 2011. The benefits of certain Vitamens on Anna Apple orchards. Agrarian Sci. (Stiinta Agricola), 2, 2528.

Mansour A.E.M., El-Shamma M.S., Shaaban E.A. and Maksoud M.A. 2010. Influence of some antioxidants on yield and fruit quality of four mango cultivars. Research J. of Agric. and Bio. Sci., 6(6), 962-965.

Mansour A.E.M., Ahmed F.F., Shaaban E.A. and Amera A.F. 2008. The beneficial of using citric acid with some nutrients for improving productivity of le-Conte pear trees. J. Agric. and Bio. Sci., 4(3), 245-250.

Mengel K., Planker R. and Hoffmann B. 1994. Relationship between leaf apoplast $\mathrm{pH}$ and $\mathrm{Fe}$ chlorosis of sunflowers (Helianthus annuus L.). J. Plant Nutr., 17, 1053-1064.

Merwad M.A., Eisa R.A. and Mostafa E.A.M. 2015. Effect of Some Growth Regulators and Antioxidants Sprays on Productivity and Some Fruit Quality of Zaghloul Date Palm. Egypt, 8(4), 1430-1437.

Miller J.E., Swanepoel J., Miller D. and Plessis S.F. 1994. Correction of lime-induced chlorosis of citrus in the Sunday's River Valley. Subtropica 15, 18-20.

Mohamed A.M.A. 2014. A Comparative Study for the Effect of Green Tea Extract and Some Antioxidants on Thompson Seedless Grapevines. Int. J. of Plant \& Soil Sci. 3(10), 1333-1342.

Mohamed A.S. 2004. Response of wheat to biofertilization and foliar application of ascorbic acid under nitrogen fertilization rates. Minia J. of Agric. Res. \& Develop., 24(4), 790-799.

Mousa I.A.I., Negm A.Y., El-Bashbishy T. and Ebrahiem-Hayat M.A. 1994. Effect of different levels and source of nitrogen fertilizers and foliar 
application of ascorbic acid and some micronutrients on wheat production in sandy soil. Fayoum J. Agric. Res. \& Dev., 8(1), 73-89.

M.A.L.R. 2017. Ministry of Agriculture and Land Reclamation, Central Administration of Agricultural Economics, Egypt. Economic Affairs Sector (EAS), Agric. Statistics, Di-rectorates of Governorates, pp. 2-4.

Naheif E.M.M. 2013. Behaviour of Wheat Cv. Masr-1 Plants to Foliar Application of Some Vitamin. Nat. Sci., 11(6), 1-5.

Obreza T.A., Alva A.K., Hanlon E.A. and Rouse R.E. 1992. Citrus grove leaf tissue and soil testing: sampling, analysis, and interpretation. Institute of Food and Agricultural Sciences, Univ. of Florida. First published: June 1992; revised: October 1999, Florida Co-op. Ext. Service, Circ. SL 115 p.

Olsen S.R., Cole C.W., Watnable S.S. and Dean L.A. 1954. Estimation of available phosphorus in soil by extraction with sodium bicarbonate. Washington: USDA Dep. Agric. Circular 939, 1-19.

Page, A., Miller, R. and Keeney, D. 1982. Methods of soil analysis, part 2. Chemical and microbiological properties. Agronomy 9, 595624.

Peter J.W., Thompson K. and Hodgson J.G. 1999. Specific leaf area and leaf dry matter content as alternative predictors of plant strategies. New Phytol., 143, 155-162.

Prusky D. 1988. The use of antioxidants to delay the onset of anthracnnose and stem end decay in avocado fruits after harvest. Plant Diseases, 72, 381-384.
Rao M.V., Koch R. and Davis K.R. 2000. Ozone a tool for probing programmed cell death in plants. Plant Mol. Biol. 44(3), 346-358.

Roshdy K.A., Saad R.I. and Abdalla B.M. 2011. Effect of some antioxidants on fruiting of Williams banana. Egypt. J. Appli. Sci., 26(3), 118127.

Shadia B.D.Y. 2017. Response of potatoes to foliar spray with cobalamin, folic acid and ascorbic acid under North Sinai conditions. Middle East J. of Agric., 06, 662-672.

Shahidi, F. and Neczk, M. 1995. Methods of Analysis and quantification of phenolic compounds food phenolic: sources, chemistry, effects and applications. Technomic publishing Company, Inc: Lancaster. USA, pp. 287-293.

Singh K.P., Chaturvedi V.K. and Bose B. 2010. Effects of salicylic acid on seedling growth and nitrogen metabolism in cucumber (Cucumis sativa L.). J. Stress Physiol. \& Bioch., 6(3), 102113.

Snedecor G.M. and Cochran W.G. 1980. Statistical methods, Sixth Edition, lowa State Univ. Press, Ames. lowa, USA.

U.P.E.H. C. 2016. Union Producers \& Exporters of Horticultural Crops Statistics, Egypt,

Vinoth K.P., Elangovan M. and Srinivasan R.S. 2017. Enzymatic and non-enzymatic antioxidant activity of Pergulariatomentosa against carbon tetra chloride induced hepatic damage in Wistar albino rats. J. of Microbiology and Biotechnology Research 7(6), 1-7. 


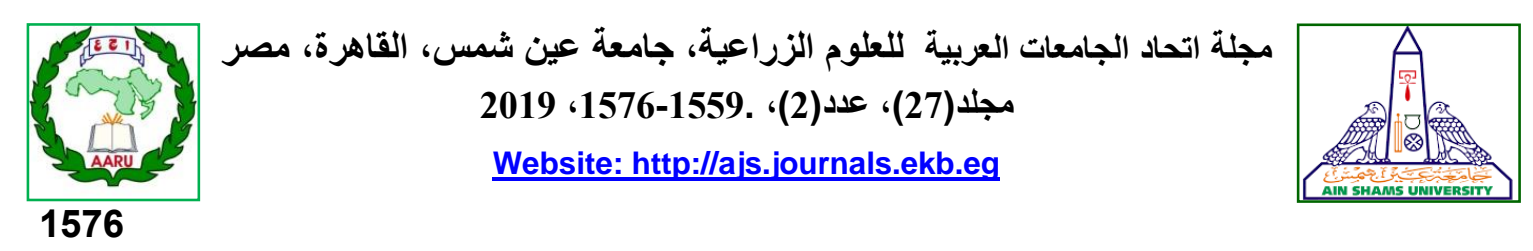

تأثير الرش ببعض مضادات الأكسدة على نمو ومحصول وجودة الثمار وإلحالة الغذائية لاثجار البرتقال بسره

[128]

\author{
إيمان محمد عبدالمنعم" - سعيد عبدالعاطي الثاذلي - أحمد عبدالفتاح الجزار - نهي أحمد منصور

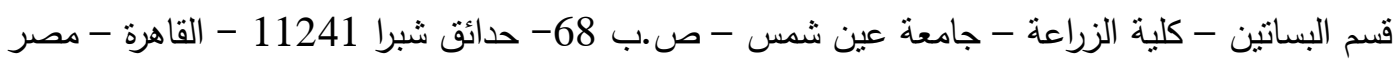

*Corresponding author: Eman Abdelmoniem@agr.asu.edu.eg

أوضحت النتائج أن الرش الورقي بتركيز 500 جزء في

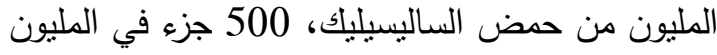

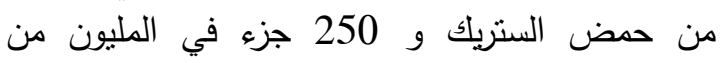

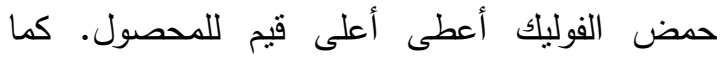

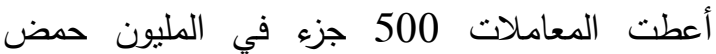

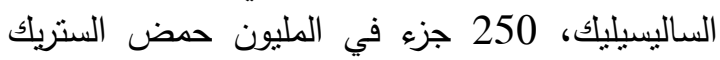
و250 جزء في المليون حمض الفوليك فيكائيك أعلى القيم

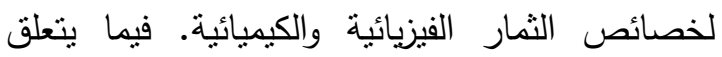

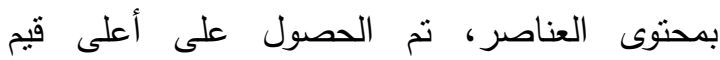
للعناصر الكبرى عن طريق رش حمض فئر الفوليك 250

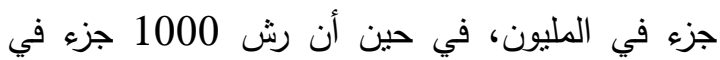

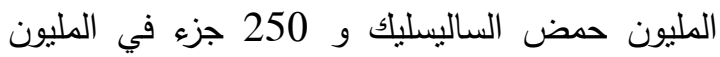
حمض الفوليك أعطى أعلى قيم للعناصر الصغرى فيك.

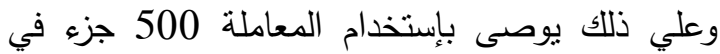
المليون من حمض الساليسيليك من الناحية الاقتصادية الئية

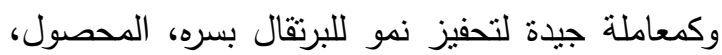

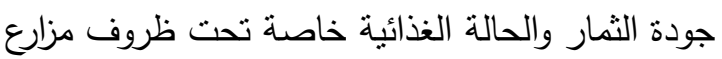
الموالح القديمة.

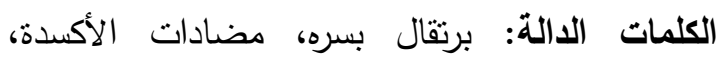
حض الستريك، حمض الفوليك، حمض الساليسيليك،

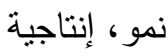

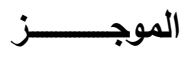

أجريت هذه الدراسة خلال موسمين متتاليين

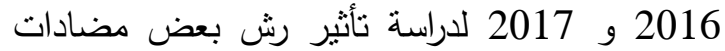
الأكسدة على النمو الخضري، المحصول، جودة لثرة الثمار

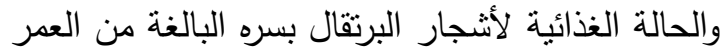

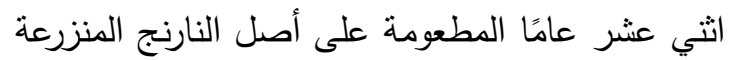

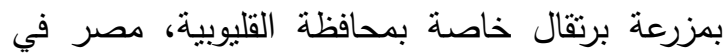

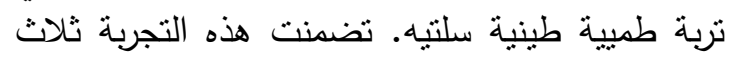

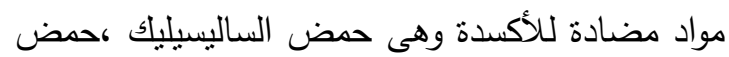

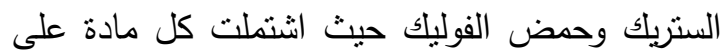

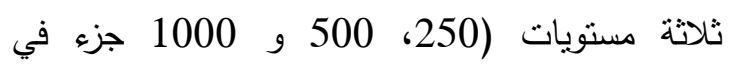
المليون) بالإضافة إلى معاملة المقارنة وعلى ذلى ذلك

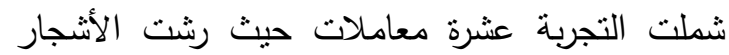

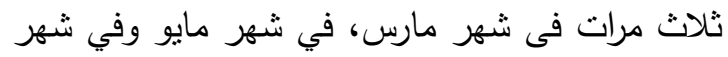

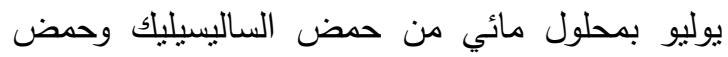
الستريك وحمض الفوليك حيث نم الحصول على على أعلى منى قيم للنمو الخضرى من خلال رش 500 جزء في المليون من حمض الساليسيليك، 1000 جزء في في جني المليون من حمض الستريك و 500 جزء في المليون من حمض الفوليك. اما فيما بتعلق بالمحصول، فئرن 